\title{
LISTRIODON SKULL FROM THE LATE MIDDLE MIOCENE OF NEBISUYU (ÇANAKKALE - MN 8) TURKEY
}

\author{
MARTIN PICKFORD ${ }^{1, *}$, TANJU KAYA ${ }^{2}$, SERDAR MAYDA ${ }^{3}$ \\ 1 UMR 7207 CR2P - MNHN-CNRS-SU, Muséum national d'Histoire naturelle, 8, rue Buffon, 75005, Paris; e-mail: martin.pickford@mnhn.fr. \\ 2 Ege University Faculty of Science, Bornova-Izmir, Turkey; e-mail: tanju.kaya@ege.edu.tr. \\ ${ }^{3}$ Ege University Faculty of Science, Biology Department, Bornova-Izmir, Turkey; e-mail: serdar.mayda@ege.edu.tr. \\ * corresponding author
}

Pickford, M., Kaya, T., Mayda, S. (2020): Listriodon skull from the late middle Miocene of Nebisuyu (Çanakkale - MN 8) Turkey. - Fossil Imprint, 76(2): 252-269, Praha. ISSN 2533-4050 (print), ISSN 2533-4069 (on-line).

\begin{abstract}
The late middle Miocene (MN 8) sediments at Nebisuyu, in the southwestern extremity of the Gelibolu Peninsula, Turkey, yielded remains of a large individual of Listriodon splendens: a skull lacking the premaxillae but containing both cheek tooth rows, and a detached left maxilla fragment containing a canine. The material evidently represents a male individual on the basis of the large dimensions of the canine, an inference borne out by the presence of a horn-like protuberance on the thickened frontal bones. The dentition is typical of the large "subspecies" Listriodon splendens major Roman, 1907. The presence of an ossicone suggests that head-to-head combat was an aspect of the behaviour of Listriodon, just as it is in several extant suid taxa. The Nebisuyu discovery extends the geographic distribution of the subspecies well to the east of its previously known range.
\end{abstract}

Key words: Listriodontinae, biogeography, behaviour, sexual selection, ossicone

Received: June 14, 2020 | Accepted: August 20, 2020 | Issued: December 30, 2020

\section{Introduction}

Neogene deposits in Çanakkale, Turkey, have long been known to yield fossils of various ages (Newton 1904). A skull of Listriodon splendens lacking the premaxillae was recovered at Nebisuyu in the Alçitepe area, in the southwestern part of the Galipoli Peninsula (Kaya 1989, Sen 2016). The skull was associated with a maxilla fragment of a suid containing a large canine, possibly representing the same individual. The strata that yielded the fossils are correlated to MN 8 on the basis of the macro- and microfaunas that have been collected from the Alçitepe Formation (Sen 2016).

The aim of this paper is to describe and interpret the Nebisuyu suid specimens and to discuss their implications for phylogeny, palaeoecology and palaeobiogeography.

\section{Geological and faunal context}

Nebisuyu is located in the southwestern end of the Galipoli (Gelibolu) Peninsula, Turkey (Kaya 1989, Sen 2016) (Text-fig. 1).

The Neogene deposits of the Dardanelles region (Turkey) comprise sedimentary successions (Kirazlı and Alçıtepe formations) that yield abundant fossil mammalian remains (Sümengen et al. 1987, Çağatay et al. 1999, 2006), but most of the localities have never been the subject of detailed studies. Previous studies have correlated the Kirazlı Formation to MN 9-12. In this study, the Nebisuyu locality is considered to correlate more precisely to $\mathrm{MN} 8$ which is earlier than the Kirazl1 Formation.

Among these localities, Nebisuyu has yielded fossils of a huge ursid (Hemicyon), a robust anchithere (Sinohippus), a medium-sized acerathere "Hoploaceratherium cf. tetradactylum", a chalicothere "Chalicotherium grande", and a medium-sized tragulid "Dorcatherium naui" all of which were found in the lowermost part of the Kirazli Formation (Kaya and Mayda 2012). Kaya (1989) described an anchithere from the locality of Nebisuyu, Ünay and de Bruijn (1984) discussed the micromammals from the broader region on both sides of the Dardanelles, while Kayseri et al. (2014) discussed its palaeobotanic and ecological aspects.

\section{Material and methods}

The fossil skull described herein is curated at the EUNHM. It has been compared with other cranial material of Listriodon from Spain, France, Germany and Switzerland. Measurements of the teeth were made following the method outlined by Van der Made (1996). Upper teeth are given in 

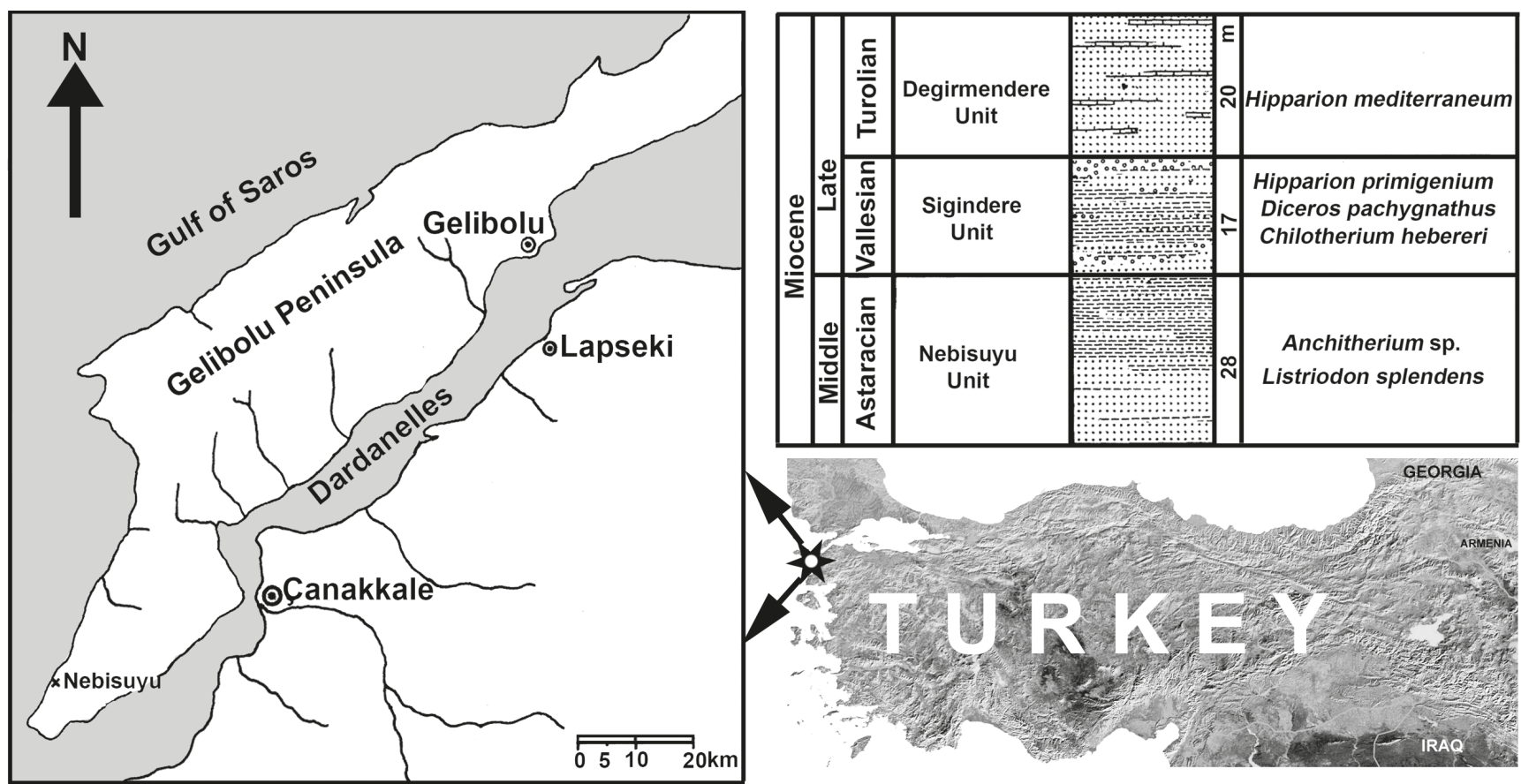

Text-fig. 1. Location and stratigraphy of Nebisuyu, Gelibolu Peninsula, Turkey (figure modified from Kaya 1989).

upper case letters (I, C, P, M - incisor, canine, premolar, molar) and lower case teeth in lower case letters (i, c, p, $\mathrm{m})$. The biochronological scale used in this paper is the European Land Mammal Zonation (Mein 1989). The catalogue number PV refers to Palaeontology, Vertebrates, followed by a unique number, in this case PV 3075.

\section{Institution abbreviations}

BSPG Bayerische Staatssammlung für Paläontologie und historische Geologie, München, Germany

CEPUNL Centro de Estratigrafia e Paleobiologia da Universidade Nova de Lisboa, Portugal

COBO Collection Olivier Bardot, Orléans, France

EUNHM Ege University Natural History Museum, Izmir, Turkey

HLD Hessisches Landesmuseum, Darmstadt, Germany

IPS Institut Català de Paleontologia Miquel Crusafont, Campus de la UAB, Cerdanyola del Vallès, Barcelona, Spain (previously Institut Paleontológic Dr. M. Crusafont, Sabadell)

IPUW Institut für Paläontologie der Universität Wien, Vienna, Austria

IVAU lnstituut voor Aardwetenschappen, Utrecht, the Netherlands

MGL Le Musée des Confluences (previously Muséum Guimet), Lyon, France

MGM Museo Geominero, Instituto Geológico y Minero de España, Madrid, Spain

MGSCB Museu i Laboratori de Geologia del Seminari, Barcelona, Spain

MHNC Musée d'Histoire naturelle, La Chaux-deFonds, Switzerland

MHNCHF Musée d'Histoire naturelle, La Chaux-deFonds, Switzerland

ML Museu Nacional de História Natural, Lisbon, Portugal
MNCN Museo Nacional de Ciencias Naturales, Madrid, Spain

MNHN Muséum national d'Histoire naturelle, Paris, France

MPV Museo Paleontológico de Valencia, Valencia, Spain

MPZ Museo Paleontológico de la Universidad de Zaragoza, Zaragoza, Spain

MNSO Muséum de Sciences naturelles, Orléans, France

MTA Maden Tetkik ve Arama, Ankara, Turkey

NMB Naturhistorisches Museum, Basle, Switzerland

NMM Naturhistorisches Museum Mainz, Mainz, Germany

NSSW Naturmuseum Winterthur (previously Naturwissenschaftliches Sammlungen der Stadt, Winterthur), Switzerland

PIMUZ Paläontologisches Institut und Museum der Universität Zürich, Zürich, Switzerland

PDTFAU Paleoantropologii, Dil ve Tarih Cografya Facultesi, Ankara Universitesi, Ankara, Turkey

RGM Nationaal Natuurhistorisch Museum (formerly Rijksmuseum voor Geologie en Mineralogie), Leiden, the Netherlands

UCBL Université Claude Bernard, Lyon, France

UN Université de Neuchâtel, Neuchâtel, Switzerland

\section{Systematic palaeontology}

Order Artiodactyla Owen, 1848

Superfamily Suoidea GraY, 1821

Family Suidae GraY, 1821

Subfamily Listriodontinae GervaIS, 1859

Genus Listriodon von MEYER, 1846

Type species. Listriodon splendens vON MeYer, 1846. 
Note. Ameghino (1904) erected two species of Listriodon (Listriodon bonaerensis, Listriodon tarijensis) on the basis of suiform fossils from South America. There are some morphological resemblances between the specimens and Listriodon from Europe, but these are due to convergent evolution. The South American fossils belong to Platygonus, a Tayassuidae (Gasparini et al. 2010).

\section{Listriodon splendens vON MEYER, 1846}

Lectotype. MHNCHF 8, right I1/ in the Natural History Museum, La Chaux-de-Fonds, figured by Stehlin (1900: pl. 5, fig. 22). Lectotype designated by Van der Made (1996: 100, pl. 41, fig. 1a, b, c and 2c - the latter is mislabelled as MHNCHF 8' left I1/). The specimen has lost part of the root since being figured by Stehlin (see also Bayle 1856).

Paralectotypes. According to Van der Made (1996): MHNCHF 8', left I1/; MHNCHF 56b, left c/1m; MHNCHF 10, left i/3; MHNCHF 4, left P4/; MHNCHF 9aua, left I1/; MHNCHF 48, right $\mathrm{C} 1 / \mathrm{m}$ (Calydonius tener von MeYer, 1846); MHNCHF 10x, left i/3; MHNCHF 2, right $\mathrm{m} / 3$; MHNCHF 4, left P2/; MHNCHF 10, right $\mathrm{i} / 3$; MHNCHF 6, left i/1; MHNCHF 6, right i/1; MHNCHF 45 , right $\mathrm{C} 1 / \mathrm{m}$ (one of the syntypes of Calydonius trux voN MEYer, 1846).

Material associated with the lectotype. According to Van der Made (1998), plate 1: MHNC 48, left $\mathrm{C} 1 / \mathrm{m}$ (contradiction of side with Van der Made 1996); MHNC 9aua, left I1/; MHNC, right cuboid; MHNC 6, right $\mathrm{i} / 1$; MHNC 10x, left i/3; MHNC, left calcaneum; plate 2: MHNC, right astragalus; MHNC, left navicular; MHNC, right magnum.

A note on the subdivision of the species Listriodon splendens. Van der Made (1996) proposed a tripartite subdivision of Listriodon splendens with chronological connotations, the lineage being interpreted as increasing in dimensions over geological time from small Listriodon splendens tapirotherium (DE BlainviLle, 1847) to medium-sized Listriodon splendens splendens VON MEYER, 1848, and thence to large Listriodon splendens major Roman, 1907. He also referred to this sequence as evolutionary stages I, II and III. Stage I was considered to be typical of early MN 6, stage II characteristic of the transition MN 6-7, whereas stage III was reported to occur at the transition MN 8-9. Pickford and Morales (2003) reported the presence of a huge specimen from Toril, Spain, that challenged this scheme because Toril is correlated to MN 7, but in general, the sequence appears to be sound.

The naming of the large subspecies of Listriodon splendens is problematic in that some of the material from La Chaux-de-Fonds is large, falling into the range of variation of L. s. major, yet it has a prior name trux voN MeYer, 1846. The available evidence suggests that trux rather than major is likely to be the valid name for this subspecies. The differences in dimensions of the sample from La Chaux-de-Fonds could reflect sexual bimodality rather than the presence of two species or subspecies, but the available material is too restricted to resolve the issue. In essence, the problem is one of nomenclature. Should $L$. $S$. major be called L. s. trux?
Material from Nebisuyu. EUNHM PV 3075, skull lacking the premaxillae, and left maxilla fragment containing the canine.

D e s c r i p t i o n. Skull. In dorsal view (Text-fig. 2), the frontal bone dominates the skull, not only by its relatively great breadth, but also by its massiveness, its somewhat rugose surface and the thickness of the bone, extending even onto the post-orbital process. The anterior parts of the frontal bones narrow markedly and descend towards the nasals at a steep angle, and are scored by two deep, parallel, grooves that link distally to the supra-orbital foramina. The supra-orbital foramina are poorly exposed but lie about half way down the steeply sloping anterior surface of the frontal. The frontals are domed upwards between the lachrymals, and are so swollen that they overhang the latter bones to a small extent. Careful scrutiny of the frontal dome reveals the presence of a suture all around the top of the frontal, on top of which is a bony apophysis, the apex of which has broken off. The broken base of the apex is oval and measures $50 \mathrm{~mm}$ antero-posteriorly by $31 \mathrm{~mm}$ bilaterally. This bony apophysis resembles an ossicone rather than a horn, since its origin appears to have been dermal. The lachrymal foramina are not preserved.

The parietals posterior to the frontals are not swollen and the surface of the bones is smooth. The temporal crests are far apart, but because the skull is slightly crushed, there is an irregular ridge running along the midline, but this should not be confused with a sagittal crest, although it could represent a distal extension of the suprafrontal structure or ossicone. The posterior margin of the neurocranium is incurved rather than rectilinear.

The distal extremities of the zygomatic arches are visible in dorsal view, and they terminate about half way between the posterior margin of the orbit and the nuchal ridge at the rear of the skull.

Finally, in dorsal view, it is possible to make out that the zygomatic arches slope laterally and ventrally to a marked extent, but because the lateral edges of the structures are broken off on both sides it is not possible to determine the diameter of the skull at this point, nor whether the zygoma possessed laterally projecting apophyses. They do, however, have a rugose upper surface and are dorso-ventrally thickened, which is rather unusual in a suid context.

In lateral view (Text-figs 3,4), it is once again the frontal bones that dominate the skull. They comprise a solid dome-like structure above the lachrymals, the swollen and somewhat rugose bone surface extending posteriorly onto the post-orbital processes, which are themselves enlarged antero-posteriorly and thicker than is usual in suid skulls. The suture between the frontal and the lachrymal is well exposed on both sides. The anterior parts of the frontals descend steeply towards the nasals before curving anteriorly. The nasals are broken off.

The anterior margin of the orbits is about $13 \mathrm{~mm}$ behind the distal extremity of the M3/ and are positioned high in the skull. Distortion makes it difficult to estimate the original dimensions of the orbits.

Posteriorly, the temporal fossae are clear and deeply excavated. The zygomatic arches are large and form a massive base to the orbits. However, their lateral extremities 


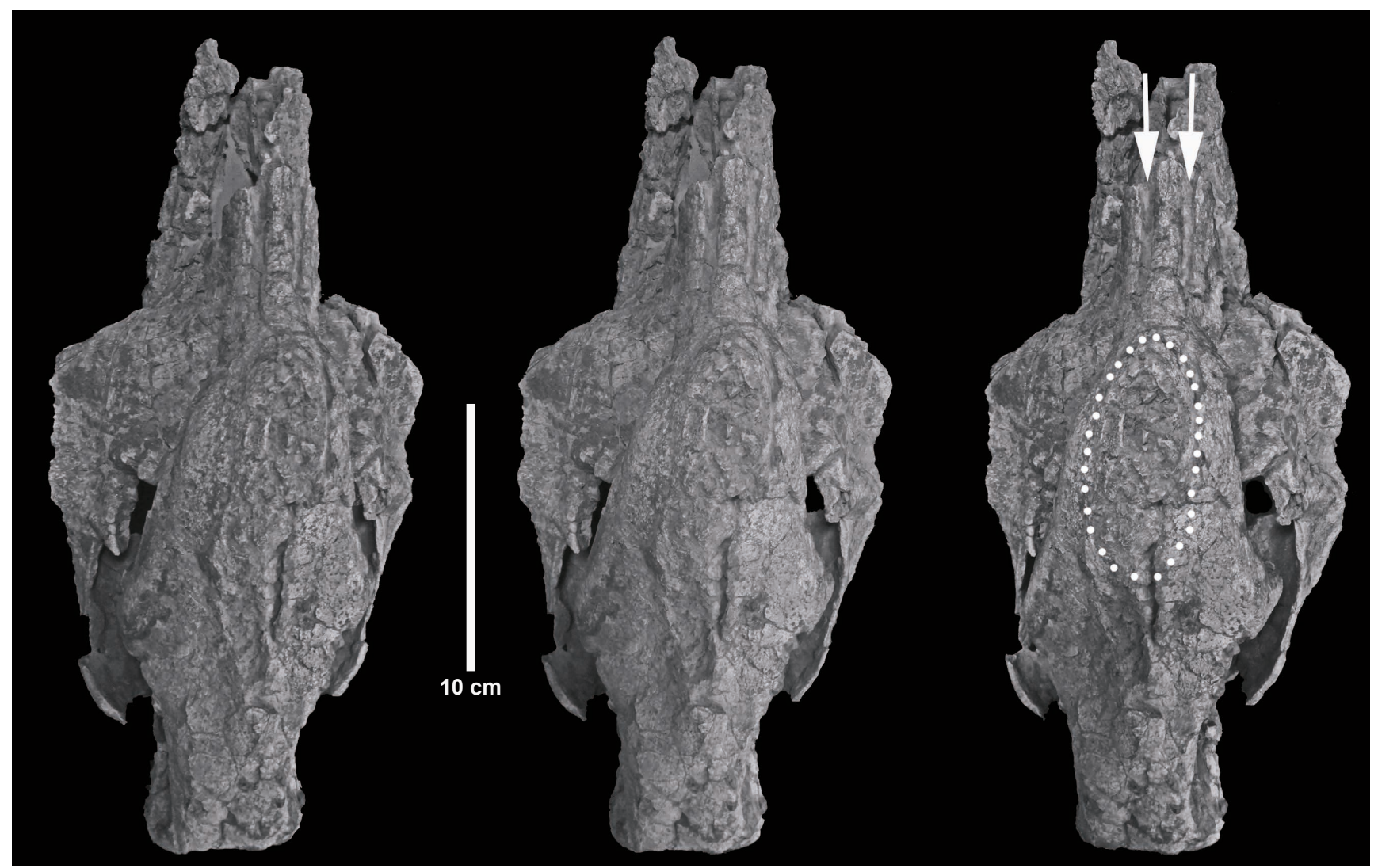

Text-fig. 2. Stereo dorsal views of the skull of Listriodon splendens from Nebisuyu, Turkey (EUNHM PV 3075). Arrows show the two grooves associated with the supraorbital foramina.

have been broken off, so it is not possible to ascertain their original extent.

The occipital condyles are small and lie only slightly above the level of the plane of the cheek teeth and well beneath the level of the orbits. The paroccipital processes are short and are directed ventro-distally.

In ventral view (Text-fig. 5), the palate is observed to extend beyond the distal ends of the M3/s by about $22 \mathrm{~mm}$ (estimated due to damage). The zygomatic arches more than double the breadth of the skull, but to what extent is difficult to estimate due to the fact that the lateral parts of both zygoma are broken off. The root of the zygomatic process of the maxilla is far back, opposite the front of M3/. The tooth rows diverge gently from fore to aft, but the skull is slightly crushed and the palate has been partly reconstructed so this divergence may be somewhat altered by post-mortem

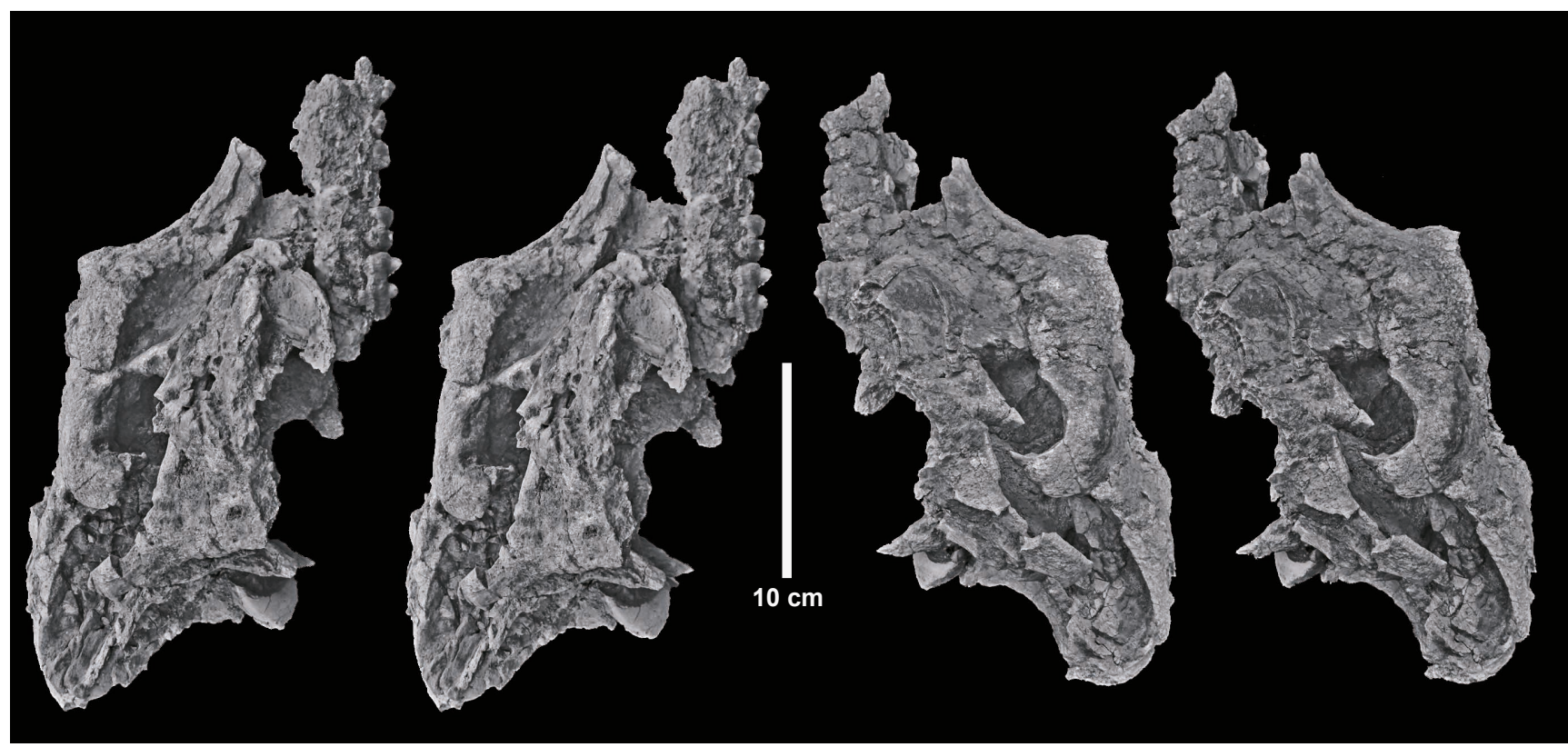

Text-fig. 3. Stereo lateral views of the skull of Listriodon splendens from Nebisuyu, Turkey (EUNHM PV 3075). 

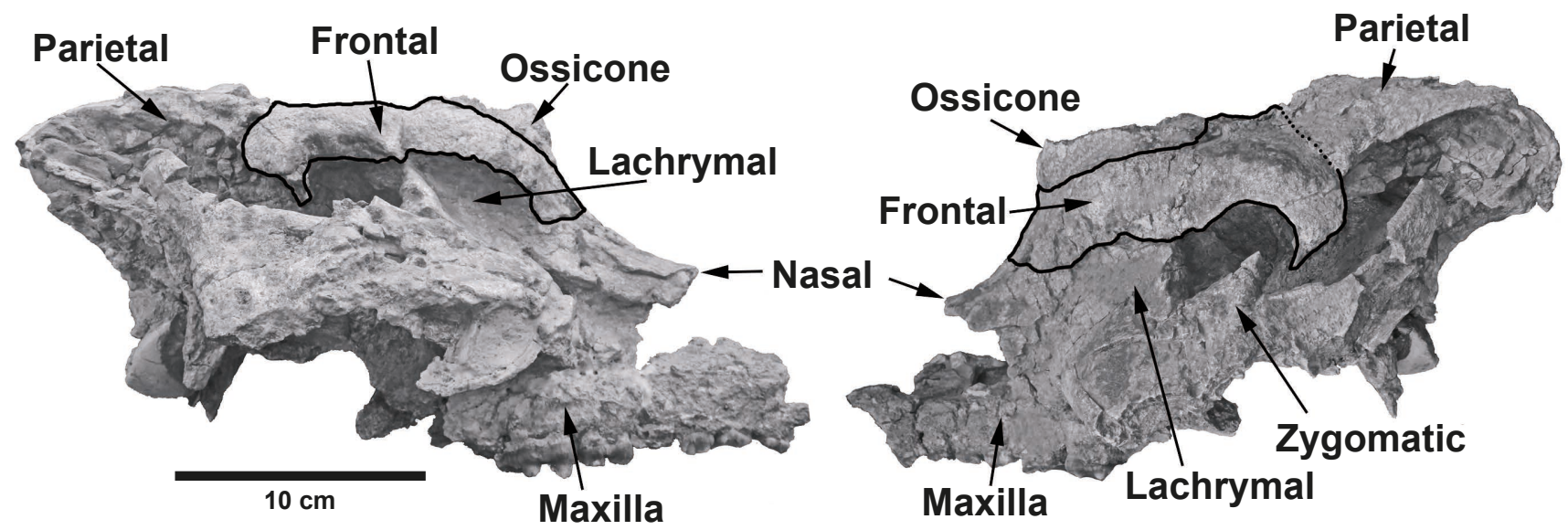

Text-fig. 4. Lateral views of the skull of Listriodon splendens from Nebisuyu, Turkey (EUNHM PV 3075), with interpretation of the bony structures surrounding the thickened frontal bones outlined in black.

distortion. The occipital condyles appear to be small for such a massive skull, and the paroccipital processes are short and are oriented ventro-distally. Much of the basicranium is preserved, but the state of preservation does not permit accurate description or interpretation.

In supero-anterior view (Text-fig. 6), there are two aspects of the skull which are striking to the eye. The first is the narrowness of the snout, the second is the massiveness of the frontal zone which dominates the area above the orbits. The two grooves linked to the supraorbital foramina are deep and subparallel, coursing along the dorsal part of the frontals. The foramina from which they emerge are poorly preserved, partly due to damage, but partly due to thickening of the frontal bone which has a distinctly rugose surface which contrasts vividly with the smooth bone of the lachrymals beneath them.
In supero-anterior view the base of the ossicone structure is clearly visible, forming an apophysis above the thickened and domed frontal bone and marked by a suture (subtle but clearly visible in glancing light). This ossicone is located above and anterior to the orbits in the anterior part of the frontal dome, the main part of which lies between the orbits. In this view, the thickening of the post-orbital processes is clearly evident, the bones forming a massive margin at the rear of each orbit. This contrasts with the sharp edges of the rear extremities of the zygomatic arches which form the margins of the temporal fossae.

In distal view, the point that leaps to the attention is the deeply concave nuchal area of the neurocranium. The upper margins of the depression are thickened laterally and dorsally, and gradually diminish in thickness as they

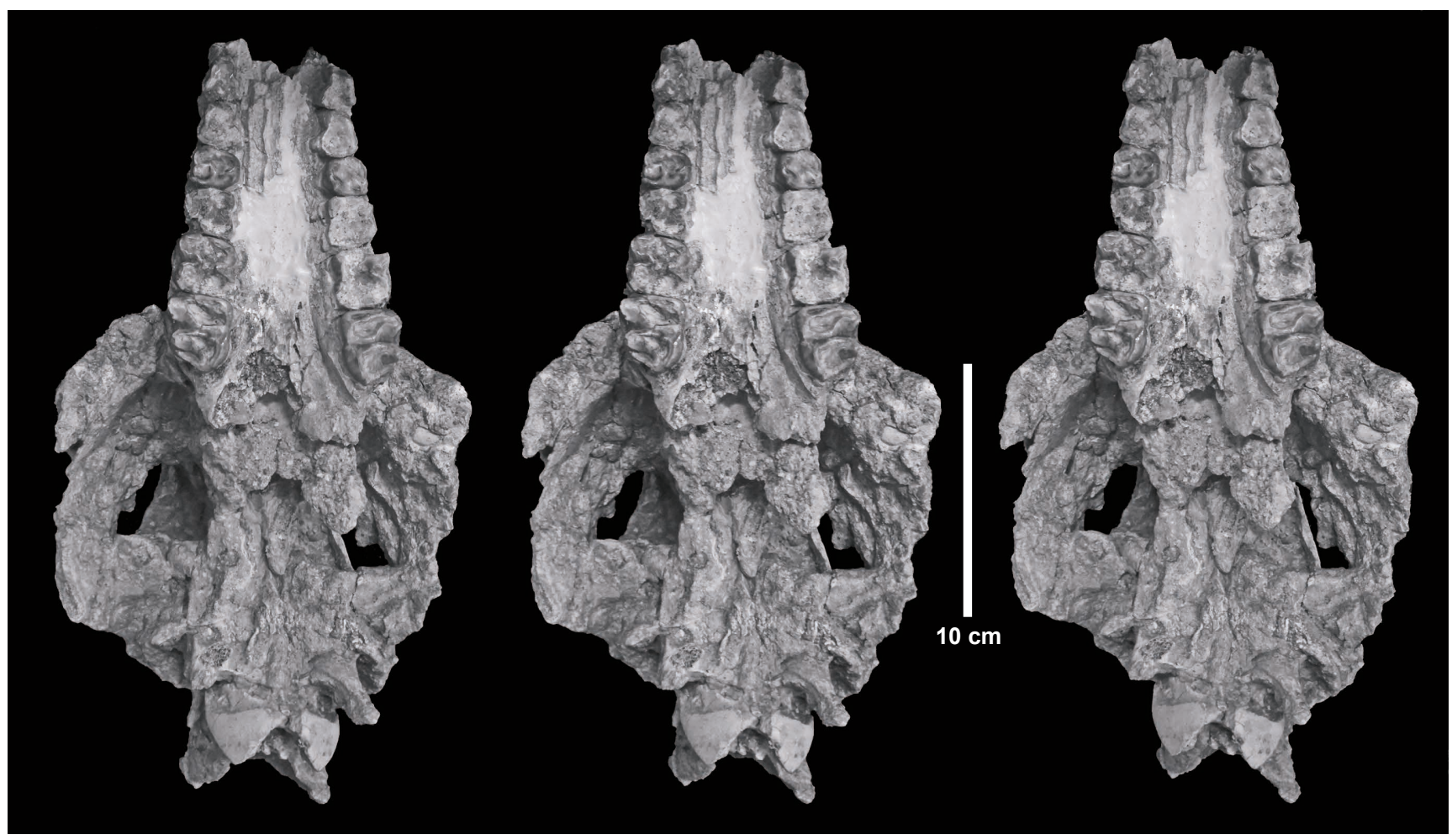

Text-fig. 5. Stereo palatal views of the skull of Listriodon splendens from Nebisuyu, Turkey (EUNHM PV 3075). 


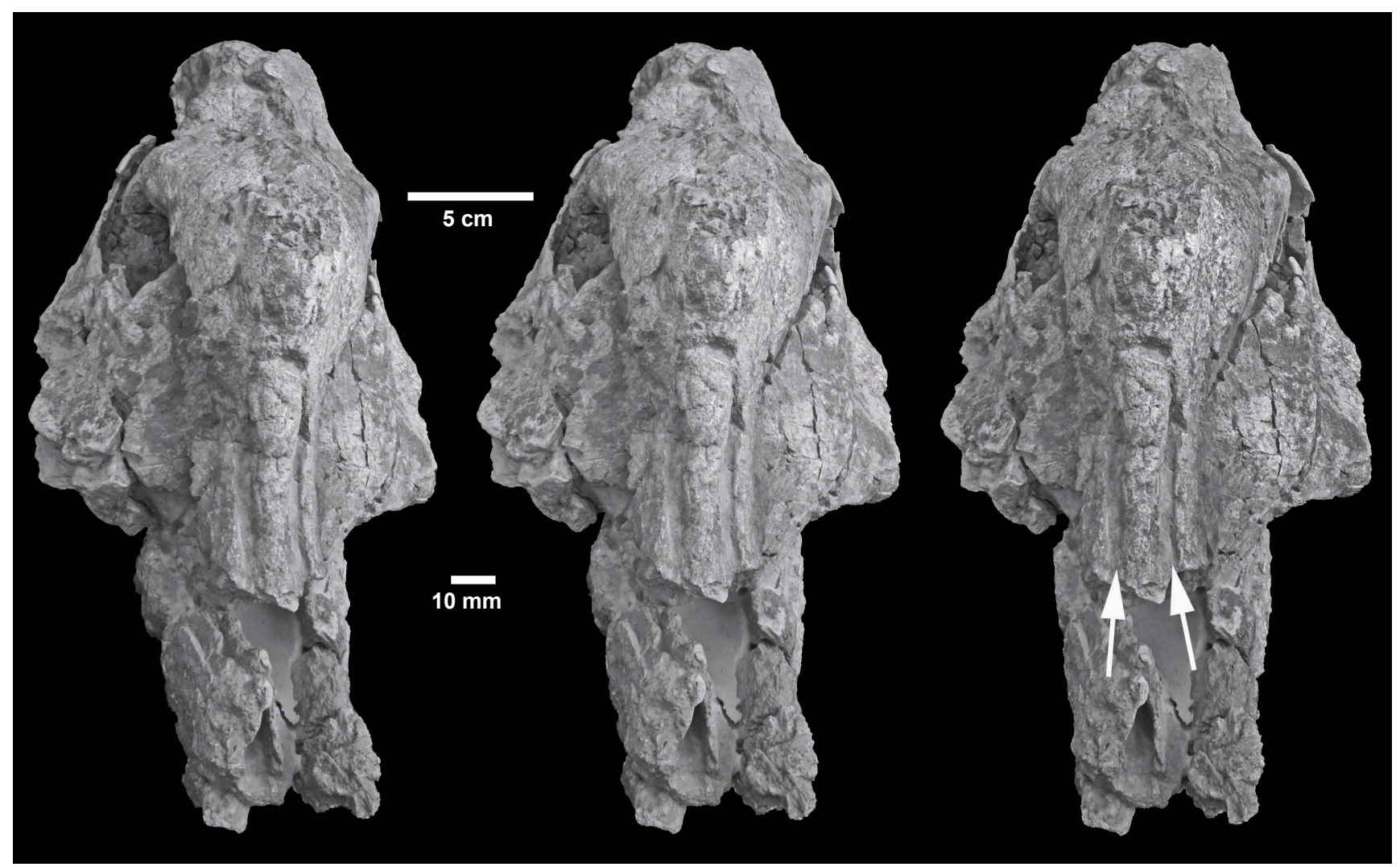

Text-fig. 6. Stereo supero-anterior views of the skull of Listriodon splendens from Nebisuyu, Turkey (EUNHM PV 3075). Arrows show the two grooves associated with the supraorbital foramina (scales are $\mathbf{1 0} \mathbf{~ m m}$ for the anterior part of the frontal bones, and $5 \mathrm{~cm}$ for the parietals).

approach the occipital condyles, where they form a V-shaped junction in the mid-line of the skull.

In posterior view (Text-fig. 7) the paroccipital processes are short and oriented vertically just to the lateral side of the occipital condyles. They extend barely a cm beyond the lowest point of the condyles.

Dentition. The palate retains heavily worn P2/-M3/ on both sides (Text-fig. 8).

The $\mathrm{P} 2 /$ and $\mathrm{P} 3 /$ are worn to stubs revealing little about their occlusal cusp morphology. On the buccal sides of both the $\mathrm{P} 2$ / and the $\mathrm{P} 3 /$, there is a low, beaded cingulum, while a depression on the lateral surface of each tooth indicates that there was likely a metacone in these two teeth, now largely eliminated by wear. The occlusal outline of each tooth is triangular with rounded corners. P4/ is heavily worn but shows three cusps, the protocone and paracone forming an anterior loph, and the metacone somewhat isolated in the disto-buccal corner of the crown. There are remnants of mesial and distal cingula. M1/ and M2/ are reduced to stubs with no cuspal morphology discernible. The M3/ in contrast, even though

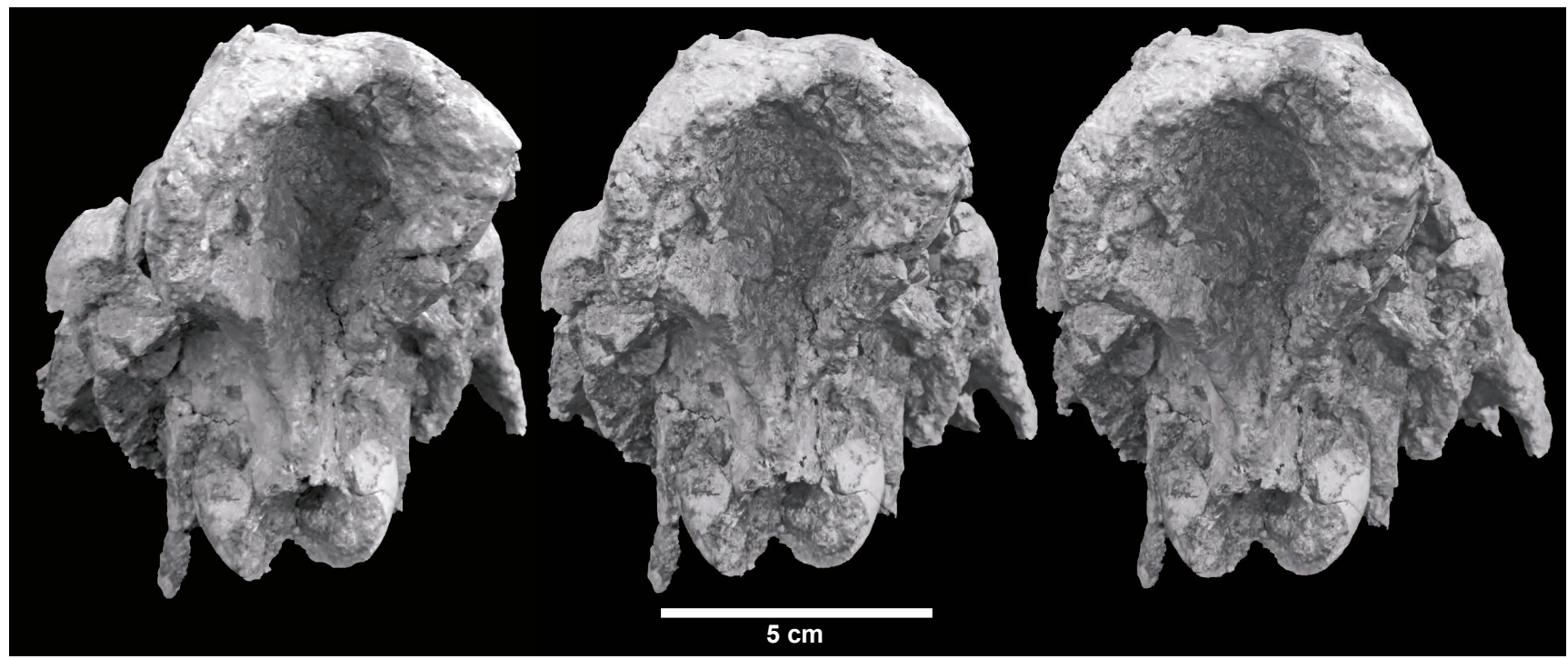

Text-fig. 7. Stereo posterior views of the skull of Listriodon splendens from Nebisuyu, Turkey (EUNHM PV 3075). 


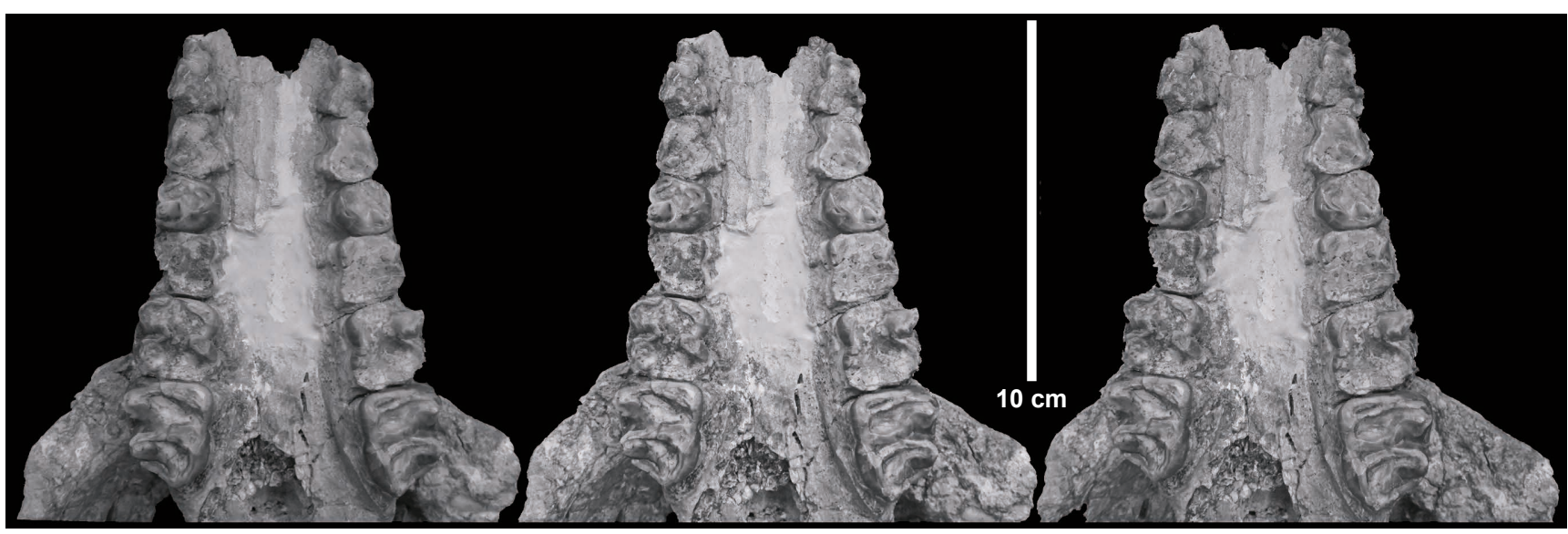

Text-fig. 8. Stereo palatal views of maxillae of Listriodon splendens from Nebisuyu, Çanakkale, Turkey (EUNHM PV 3075).

heavily worn shows two clear transverse lophs separated by a transverse valley which is not blocked by a median accessory cusplet. There is a mesial cingulum, especially evident in the mesio-lingual half of the crown, and there is a distal cingulum between the metacone and hypoconule. Wear has advanced to the stage where the protocone and paracone are joined together thereby forming a strong, slightly oblique transverse loph, and the metacone, hypocone and hypoconule are joined together, forming an obliquely oriented distal loph.

The overall aspect of the dentition of the Nebisuyu suid skull is that it is of a highly lophodont listriodont such as
Listriodon splendens, but it is not as finely lophodont as Lopholistriodon kidogosana PICKFORD et WILKINSON, 1975, which is in any case a much smaller animal (Pickford 1986). Metrically, the teeth of the Nebisuyu fossil plot into the upper part of the range of variation of dentitions of Listriodon splendens from Europe (Text-fig. 9), with the sole exception that the breadth of the P2/ slightly surpasses that of any other known specimen. However, considering its extremely worn status, measurement of the $\mathrm{P} 2 /$ had to be estimated from the roots which are known to be larger than the crown. Therefore, the seemingly very broad P2/ does not comprise

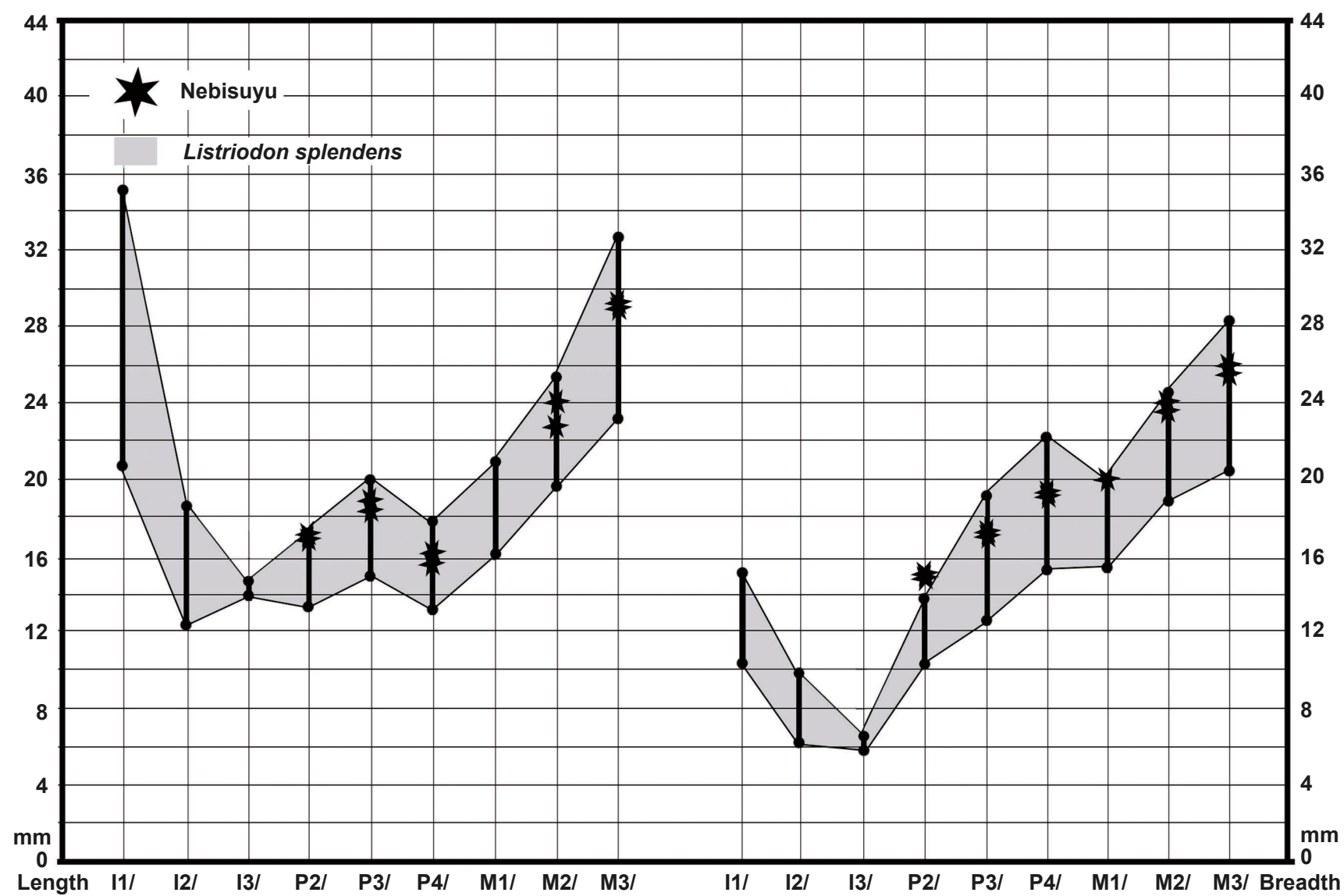

Text-fig. 9. Length and breadth diagram of upper teeth Listriodon splendens from Europe (after Pickford and Morales 2003). The cheek teeth of the Nebisuyu fossil plot into the upper part of the range of variation, close to specimens attributed to the subspecies Listriodon splendens major. 


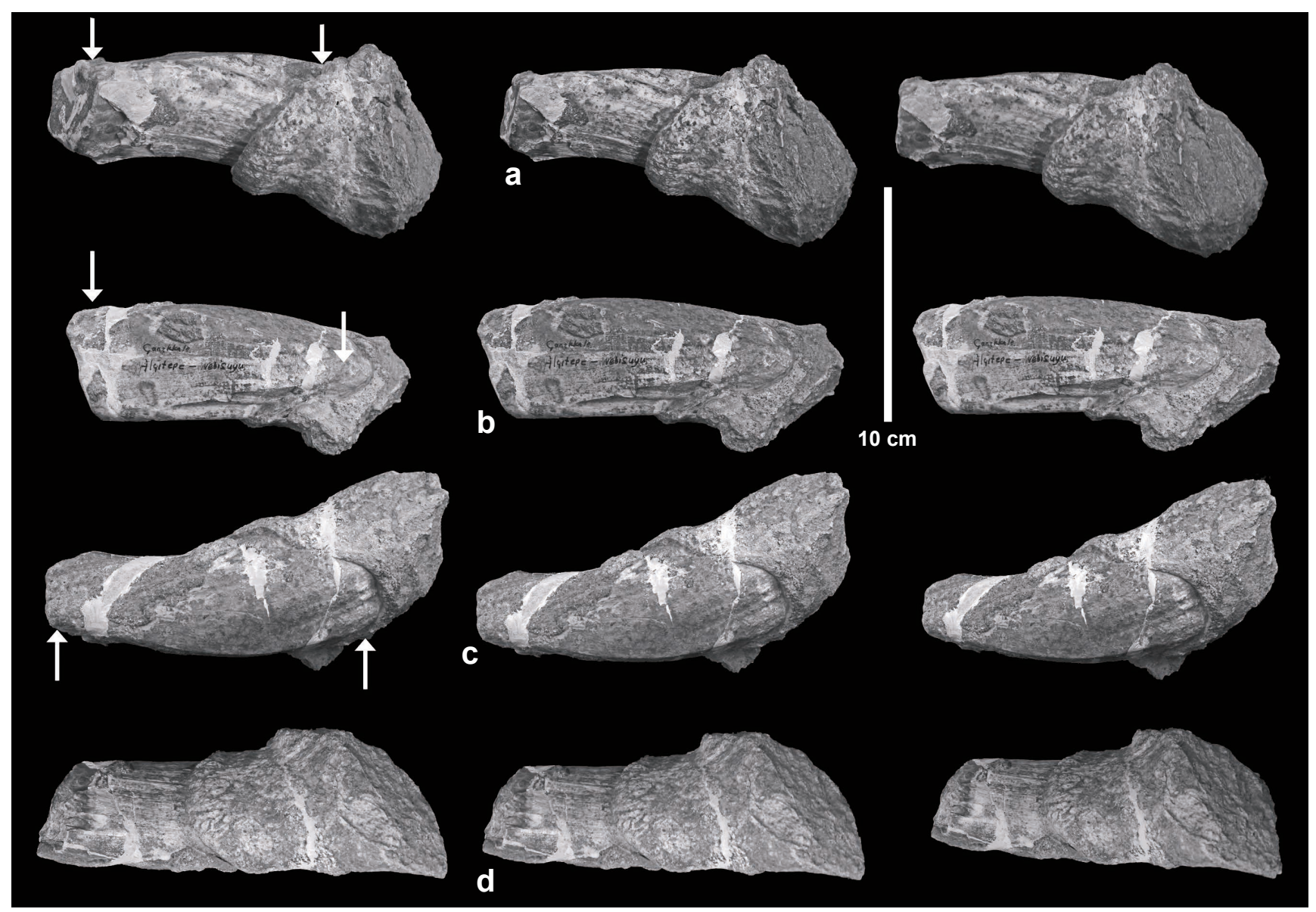

Text-fig. 10. Stereoscopic views of EUNHM PV 3075, upper left male canine in maxilla fragment from Nebisuyu, Turkey, attributed to Listriodon splendens. Radicular end is to the right. Arrows indicate extent of wear facet caused by abrasion against the lower canine. a: antero-dorsal, b: oblique anterior view, c: ventral, d: dorsal views.

a substantive argument against attributing the specimen to Listriodon splendens

If one accepts the presence of diverse subspecies of Listriodon splendens, as was the position of Van der Made (1996) then, on the basis of its large cheek teeth with a suggestion that $\mathrm{P} 2 /$ and $\mathrm{P} 3 /$ possessed distinct metacones, one would conclude that the Nebisuyu skull should be classified as Listriodon splendens major Roman, 1907, or as Listriodon splendens Evolutionary Stage III of Van der

Table 1. Measurements (in mm) of the cheek teeth in the skull of Listriodon splendens from Nebisuyu, Turkey (EUNHM PV 3075). It - left, rt - right.

\begin{tabular}{|l|c|c|}
\hline \multicolumn{1}{|c|}{ Tooth } & Mesio-distal length & $\begin{array}{c}\text { Bucco-lingual } \\
\text { breadth }\end{array}$ \\
\hline $\mathrm{P} 2 / \mathrm{lt}$ & 17.0 & 15.0 \\
\hline $\mathrm{P} 2 / \mathrm{rt}$ & 17.4 & 15.2 \\
\hline $\mathrm{P} 3 / \mathrm{lt}$ & 18.3 & 17.2 \\
\hline $\mathrm{P} 3 / \mathrm{rt}$ & 19.0 & 17.4 \\
\hline $\mathrm{P} 4 / \mathrm{lt}$ & 16.3 & 19.5 \\
\hline $\mathrm{P} 4 / \mathrm{rt}$ & 15.8 & 19.6 \\
\hline $\mathrm{M} 1 / \mathrm{lt}$ & - & 20.0 \\
\hline $\mathrm{M} 1 / \mathrm{rt}$ & - & - \\
\hline $\mathrm{M} 2 / \mathrm{lt}$ & 24.0 & 24.0 \\
\hline $\mathrm{M} 2 / \mathrm{rt}$ & 23.0 & 23.6 \\
\hline $\mathrm{M} 3 / \mathrm{lt}$ & 28.7 & 25.8 \\
\hline $\mathrm{M} 3 / \mathrm{rt}$ & 28.1 & 26.0 \\
\hline
\end{tabular}

Made (1996). Given, however, that the type specimen of Calydonius trux von Meyer, 1846, is a large upper canine from the same locality as the upper central incisor which is the lectotype of Listriodon splendens, the possibility exists that evolutionary stage III should be called either splendens or trux, both names having priority over major. The question is delicate in that the lectotype incisor, even though large within the context of Listriodon, could represent evolutionary stage II as thought by Van der Made (1996) whereas the canine attributed to Calydonius trux is rather too large to belong to this evolutionary stage, and more likely represents evolutionary stage III.

Metric analysis of the dentition. Comparisons of the dimensions of the cheek teeth of the Nebisuyu specimen with other listriodonts from Eurasia, indicates that they fall into the known range of variation of Listriodon splendens (Tab. 1). In detail the specimen corresponds closely in dimensions with material often attributed to the subspecies Listriodon splendens major ROMAN, 1907, or Listriodon splendens evolutionary stage III of Van der Made (1996) which ranges in age from the end of MN 7 to the beginning of MN 9. This subspecies was defined in the Iberian Peninsula (Aveiras de Baixo, Portugal) (Roman 1907) and has been reported from several localities in Spain (Hernandez-Pacego and Dantin Cereceda 1915, Van der Made 1996, Pickford and Morales 2003) and may occur at the type locality of Listriodon splendens, La Chaux- 
de-Fonds, Switzerland, where it is known under the name Calydonius trux von Meyer, 1846.

Huge suid canine from Nebisuyu. The locality at Nebisuyu from which the large skull of Listriodon splendens was collected also yielded a left upper male canine in a fragment of maxilla (EUNHM PV 3075) (Text-figs 10, 11). The specimen is large within the context of Listriodon, and it is possible that it represents the same individual as the skull. Large canines of Listriodon splendens are known from St Quirze and Hostalets, Spain, Bonnefont (Text-fig. 14) and La Grive, France, and La Chaux-de-Fonds, Switzerland, the last being the type specimen of Calydonius trux vON MEYER, 1846 (Van der Made 1996). The specimen from St Quirze, in particular, has almost the same antero-posterior diameter as the Nebisuyu tooth (54 mm versus $55 \mathrm{~mm}$ for the Turkish specimen) (Text-fig. 15).

The radicular part of the Nebisuyu canine is short, about $25 \mathrm{~mm}$ on the ventral side and ca. $73 \mathrm{~mm}$ dorsally where the root is covered by the canine flange. This measurement is of the same order of magnitude as that of the canine in the skull of Listriodon xinanensis CHEN, 1986 from China (Chen 1986, Van der Made 1996).

Even though the Nebisuyu canine lacks the apex (broken off or worn away, so no enamel bands are preserved) what

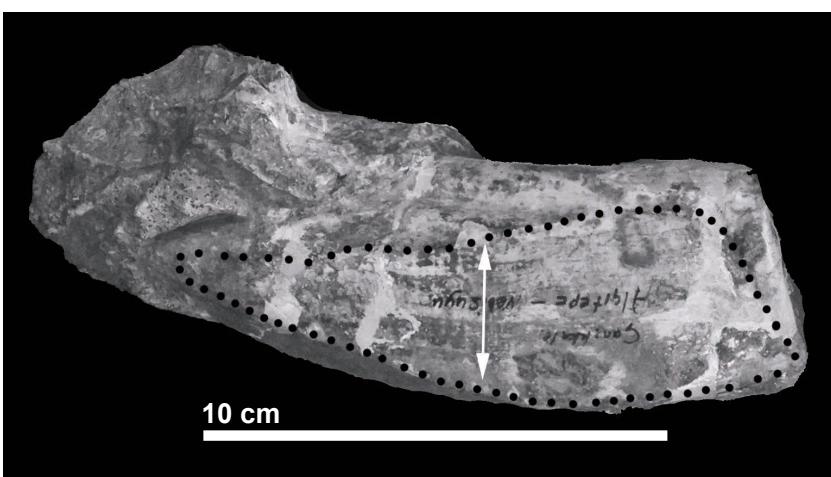

Text-fig. 11. Slightly oblique anterior view of the Nebisuyu suid canine (EUNHM PV 3075) to show the extent of the wear facet caused by thegosis against the lower canine. The double-headed arrow shows the orientation of scratches on the wear facet.

remains accords closely in morphology with a specimen of Listriodon splendens from Sinap, Turkey, but it is substantially larger. There is a prominent dorsal gutter backed by a ridge as in the specimen from Sinap (EUNHM AS 92.644) (Textfig. 12) and the anterior gutter is weakly expressed. The almost planar wear facet caused by abrasion against the lower

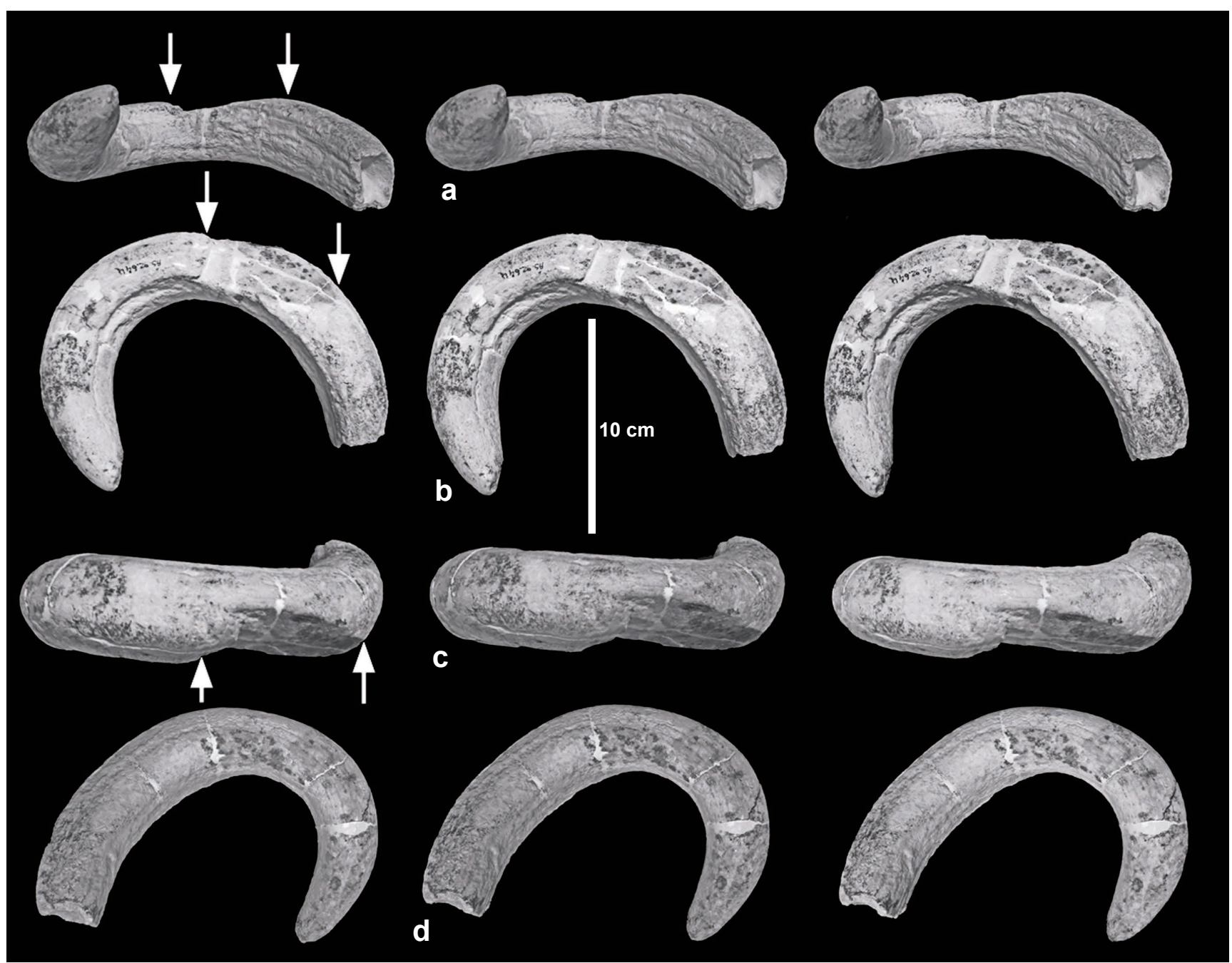

Text-fig. 12. Stereoscopic views of EUNHM AS 92-644, left upper male canine of Listriodon splendens from Sinap, Turkey. a: oblique posterior, b: oblique ventral, c: oblique anterior, $d$ : oblique superior views. The radicular end is towards to the right except in (d) where it is to the left. Arrows indicate the extent of the wear facet caused by abrasion against the lower canine. 


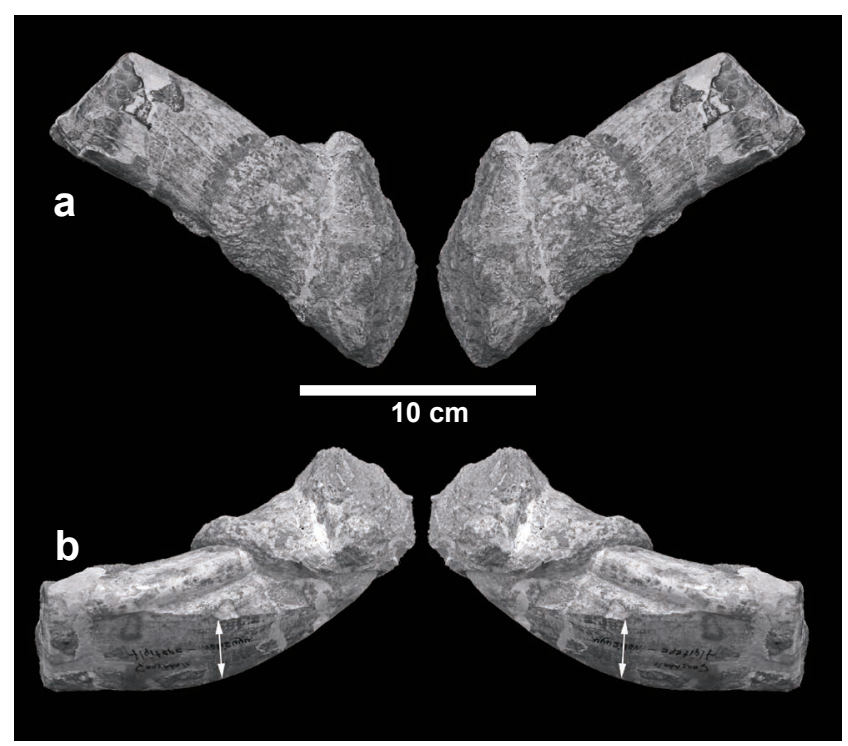

Text-fig. 13. Reconstruction of the upper canines of the Nebisuyu listriodont (EUNHM PV 3075), a: dorsal view (anterior towards top of page), b: anterior view. The twoheaded arrows show the orientation of the scratches on the wear facet caused during thegosis with the lower canine. These orientations are approximate.

canine is similar in the two specimens, with a notched outer edge which makes a prominent step on the anterior surface of the tooth. The wear facet narrows towards the root, its inner end being close to the edge of the alveolus $(21 \mathrm{~mm}$ in the Nebisuyu specimen, $14 \mathrm{~mm}$ in the Sinap tooth).
Measured from the medial end to the outer notch, the wear facet is $64 \mathrm{~mm}$ long in the Sinap specimen and $112 \mathrm{~mm}$ in the specimen from Nebisuyu. This measurement corresponds to the length of that part of the lower canine that contacts the upper canine during thegosis (Text-fig. 13).

Other unpublished material of the large variant of Listriodon splendens is known from the locality of Helsighausen, Switzerland (Text-fig. 16, Tab. 3). An upper central incisor and a right mandible with cheek teeth from fine sandstone deposits in the area falls into the upper part of the range of metric variation of the species (Tab. 2).

Some unpublished specimens of large Listriodon splendens from Hostalets, Spain, curated in other institutions, are included in order to fill out the fossil record of the taxon (Text-fig. 17).

Hernandez-Pacego and Dantin Cereceda (1915) published detailed descriptions of teeth, jaws and postcranial elements of Listriodon splendens from Cerro del Ortero, Spain, attributing the fossils to the large subspecies major. The authors also discussed and illustrated what they considered to be an unknown artiodactyl. Stehlin (in Hernandez-Pacego and Dantin Cereceda 1915: 137$138,260-261)$ in a written communication to the authors commented that, after examining casts of the latter specimens, they show affinities to Hyopotamus and more particularly to a specimen from Monte Massi, Italy, that he had identified as Anthracotherium? meneghinii, but probably representing a new genus of anthracothere. In fact all the Spanish fossils concerned are juveniles of Listriodon splendens major and are not in any way related to anthracotheres.
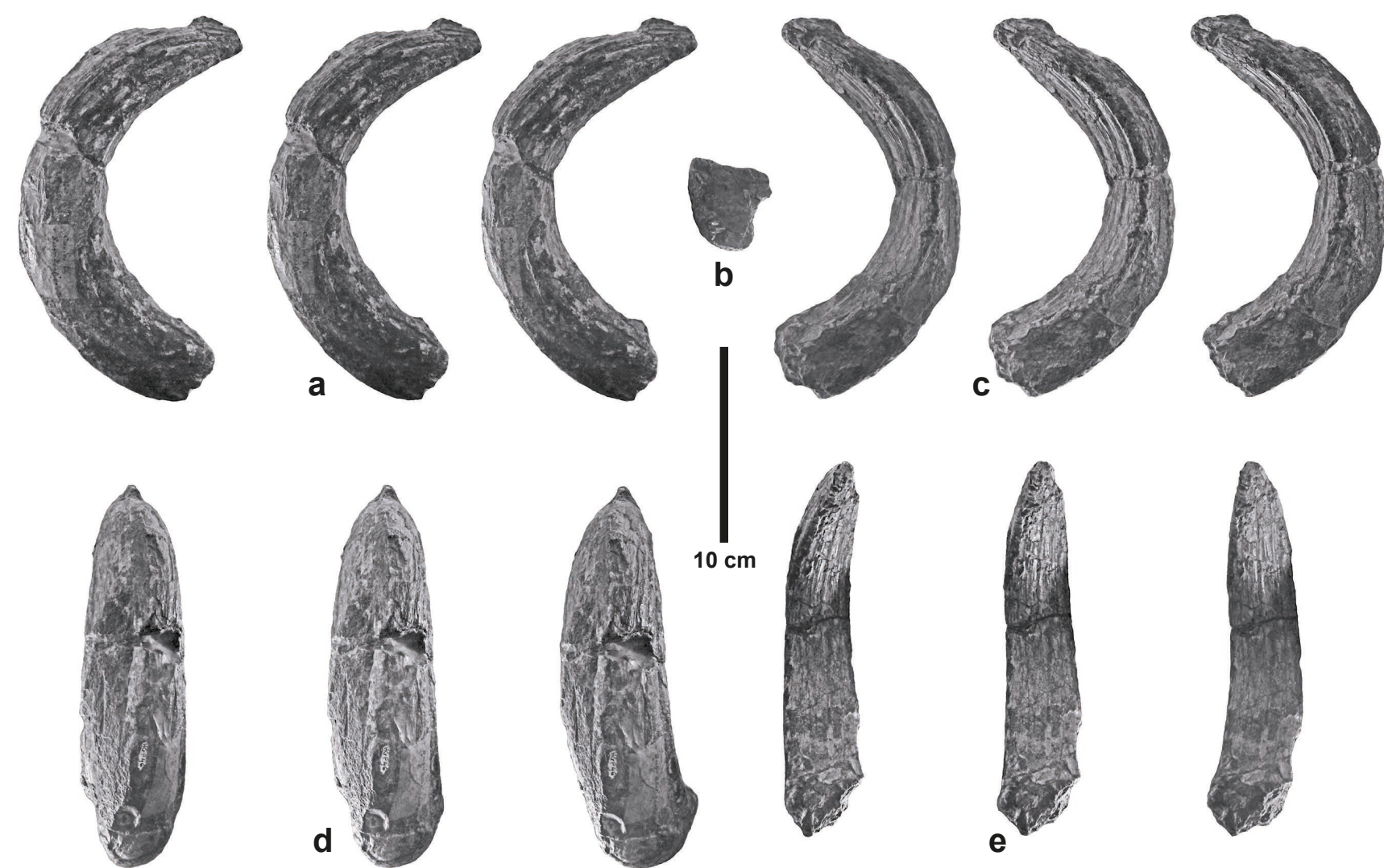

Text-fig. 14. Stereo images of MNHN HGP 46, left upper male canine of Listriodon splendens from Bonnefont, France, first published by Crouzel (1980) as Sus (?) doati. a: ventral view, b: radicular section, c: dorsal view, d: oblique lateral view, e: oblique medial view. 
Table 2. Measurements (in mm) of upper male canines of Listriodontinae from Europe and Turkey arranged by MN Zones. Dap antero-posterior diameter, Dvd - dorso-ventral diameter, lt - left, rt - right, VDM - Van der Made.

\begin{tabular}{|c|c|c|c|c|c|c|}
\hline Catalogue no. & Tooth & Dap & Dvd & Locality & Data source and comments & Correlation \\
\hline ML 5547 & $\mathrm{C} 1 /$ & 29.8 & 35.6 & Quinta da Raposa, Portugal & VDM 1996 & MN 4 \\
\hline MNCN HOT-SI 072 & $\mathrm{C} 1 / \mathrm{lt}$ & 24.0 & 18.0 & Hidroelectrica, Spain & Own, 2015 & MN 4 \\
\hline MNCN 193 & $\mathrm{C} 1 / \mathrm{lt}$ & 25.5 & 27.0 & Los Nogales, Spain & Own, 2015 & MN 4 \\
\hline MNCN 33 & $\mathrm{C} 1 / \mathrm{rt}$ & 27.0 & 28.0 & Los Nogales, Spain & Own, 2015 & MN 4 \\
\hline MNCN FMH'14 4075 & $\mathrm{C} 1 / \mathrm{rt}$ & 34.5 & 22.4 & Mahou, Spain & Own, 2015 & MN 4 \\
\hline MNHN LRM 851 & $\mathrm{C} / \mathrm{lt}$ & 25.5 & 21.0 & Pellecahus, France & Own, 2019 & MN 4 \\
\hline MPZ 6427 & $\mathrm{C} 1 / \mathrm{lt}$ & 20.5 & 22.0 & Artesilla, Spain & VDM 1996 & MN 4a \\
\hline MPV FB 52 & $\mathrm{C} 1 / \mathrm{lt}$ & 30.7 & 29.8 & Buńol, Spain & VDM 1996 & MN 4a \\
\hline IPS 1148 & $\mathrm{C} 1 / \mathrm{lt}$ & 31.4 & 30.6 & Buńol, Spain & VDM 1996 & MN 4a \\
\hline IPS & $\mathrm{C} 1 / 1 \mathrm{t}$ & 32.5 & 29.8 & Buńol, Spain & VDM 1996 & $\mathrm{MN} 4 \mathrm{a}$ \\
\hline MPV FBB 217 & $\mathrm{C} 1 / \mathrm{rt}$ & 25.2 & 18.9 & Buńol, Spain & VDM 1996 & MN 4a \\
\hline IVAU & $\mathrm{C} 1 / \mathrm{rt}$ & 26.1 & 31.0 & Buńol, Spain & VDM 1996 & MN 4a \\
\hline ML & $\mathrm{C} 1 /$ & 30.0 & 33.5 & Curelos de Cavao, Portugal & VDM 1996 & MN 4a \\
\hline CEPUNL & $\mathrm{C} 1 / \mathrm{rt}$ & 24.6 & 30.5 & Quinta da Farinheira, Portugal & VDM 1996 & MN 4a \\
\hline ML 5549 & $\mathrm{C} 1 / \mathrm{rt}$ & 28.0 & 33.0 & Quinta de Conceiçao, Portugal & VDM 1996 & MN 4a \\
\hline NMB SO 3022 & $\mathrm{C} 1 / \mathrm{rt}$ & 25.9 & 27.2 & Baigneaux, France & VDM 1996 & $\mathrm{MN} 4 \mathrm{~b}$ \\
\hline MNHN CHE 68 & $\mathrm{C} 1 / \mathrm{rt}$ & 27.2 & 27.9 & Chevilly, France & VDM 1996 & $\mathrm{MN} 4 \mathrm{~b}$ \\
\hline MNHN CHE 32 & $\mathrm{C} 1 / \mathrm{rt}$ & 31.6 & 26.6 & Chevilly, France & VDM 1996 & $\mathrm{MN} 4 \mathrm{~b}$ \\
\hline MSNO 231 & $\mathrm{C} 1 / \mathrm{rt}$ & 24.0 & 26.5 & Chevilly?, France & VDM 1996 & $\mathrm{MN} 4 \mathrm{~b}$ \\
\hline UCBL 320303 & $\mathrm{C} 1 / \mathrm{rt}$ & 23.3 & 28.0 & La Romieu, France & VDM 1996 & $\mathrm{MN} 4 \mathrm{~b}$ \\
\hline UCBL 320303 & $\mathrm{C} 1 / \mathrm{rt}$ & 25.0 & 22.1 & La Romieu, France & VDM 1996 & $\mathrm{MN} 4 \mathrm{~b}$ \\
\hline UCBL 320281 & $\mathrm{C} 1 / \mathrm{rt}$ & 26.1 & 26.3 & La Romieu, France & VDM 1996 & MN 4b \\
\hline CEPUNL 25 & $\mathrm{C} 1 / \mathrm{lt}$ & 26.7 & 31.7 & Olival da Susana, Portugal & VDM 1996 & $\mathrm{MN} 4 \mathrm{~b}$ \\
\hline CEPUNL 26 & $\mathrm{C} 1 / \mathrm{rt}$ & 21.6 & 26.5 & Olival da Susana, Portugal & VDM 1996 & $\mathrm{MN} 4 \mathrm{~b}$ \\
\hline ML 5544 & $\mathrm{C} 1 /$ & 26.1 & 28.2 & Quinta Grande, Portugal & VDM 1996 & MN 4b \\
\hline MNHN FP 225 & $\mathrm{C} 1 / \mathrm{lt}$ & 29.2 & 32.0 & Pontlevoy, France & VDM 1996 & MN 5 \\
\hline MNHN FP 739 & $\mathrm{C} 1 / \mathrm{rt}$ & 30.7 & 31.7 & Pontlevoy, France & VDM 1996 & MN 5 \\
\hline NMB 546 cast & $\mathrm{C} 1 / \mathrm{lt}$ & 24.5 & 30.5 & Ravensberg, Germany & VDM 1996 & MN 5 \\
\hline NMB TD 545 & $\mathrm{C} 1 / \mathrm{rt}$ & 28.2 & 32.4 & Ravensberg, Germany & VDM 1996 & MN 5 \\
\hline COBO & $\mathrm{C} 1 / \mathrm{rt}$ & 25.9 & 29.1 & Tavers, France & VDM 1996 & MN 5 \\
\hline NSSW 113 & $\mathrm{C} 1 / \mathrm{lt}$ & 31.5 & 34.7 & Veltheim, Austria & VDM 1996 & MN 5 \\
\hline MTA CA $1 / 2$ & $\mathrm{C} 1 / \mathrm{rt}$ & 28.2 & 24.2 & Çandir, Turkey & VDM 1996 & MN 6 \\
\hline PIMUZ CA V/21 & $\mathrm{C} 1 / \mathrm{rt}$ & 49.3 & 40.6 & Çandir, Turkey & VDM 1996 & MN 6 \\
\hline MTA AKI 3/588 & $\mathrm{C} 1 / \mathrm{lt}$ & 31.2 & 28.5 & Inönü, Turkey & VDM 1996 & MN 6 \\
\hline MTA AKI 3/332 & $\mathrm{C} 1 / \mathrm{rt}$ & 27.7 & 34.0 & Inönü, Turkey & VDM 1996 & MN 6 \\
\hline MTA AKI 3/327 & $\mathrm{C} 1 / \mathrm{rt}$ & 31.9 & 36.0 & Inönü, Turkey & VDM 1996 & MN 6 \\
\hline MTA AKI 3/325 & $\mathrm{C} 1 / \mathrm{rt}$ & 32.6 & 41.1 & Inönü, Turkey & VDM 1996 & MN 6 \\
\hline IPUW 18 IX 15 & $\mathrm{C} 1 / \mathrm{lt}$ & 24.2 & 25.9 & Klein Hadersdorf, Austria & VDM 1996 & MN 6 \\
\hline IPUW 18 IX 15 & $\mathrm{C} 1 / \mathrm{lt}$ & 26.8 & 27.7 & Klein Hadersdorf, Austria & VDM 1996 & MN 6 \\
\hline IPS 1101 & $\mathrm{C} 1 / \mathrm{lt}$ & 24.4 & 22.0 & Manchones 1, Spain & VDM 1996 & MN 6 \\
\hline IVAU AR IV 60 & $\mathrm{C} 1 / \mathrm{lt}$ & 26.2 & 30.3 & Manchones 2, Spain & VDM 1996 & MN 6 \\
\hline MPZ AV-21 & $\mathrm{C} 1 / \mathrm{lt}$ & 29.7 & 33.2 & Manchones 2, Spain & VDM 1996 & MN 6 \\
\hline RGM 263.162 & $\mathrm{C} 1 / \mathrm{lt}$ & 31.0 & 31.3 & Manchones 2, Spain & VDM 1996 & MN 6 \\
\hline RGM 262.972 & $\mathrm{C} 1 / \mathrm{rt}$ & 30.0 & 32.7 & Manchones 2, Spain & VDM 1996 & MN 6 \\
\hline IVAU ARIV 398 & $\mathrm{C} 1 / \mathrm{rt}$ & 30.4 & 27.4 & Manchones 2, Spain & VDM 1996 & MN 6 \\
\hline IVAU AR IV 64 & $\mathrm{C} 1 / \mathrm{rt}$ & 30.5 & 32.3 & Manchones 2, Spain & VDM 1996 & MN 6 \\
\hline PDTFAU G987 & $\mathrm{C} 1 / \mathrm{lt}$ & 32.2 & 40.4 & Pasalar, Turkey & VDM 1996 & MN 6 \\
\hline PDTFAU G114 & $\mathrm{C} 1 / \mathrm{rt}$ & 30.7 & 36.6 & Pasalar, Turkey & VDM 1996 & MN 6 \\
\hline MNHN Sa 4317 & $\mathrm{C} 1 /$ & 21.0 & 28.5 & Sansan, France & VDM 1996 & MN 6 \\
\hline BSPG 1957 I 194 & $\mathrm{C} 1 / \mathrm{lt}$ & 24.4 & 27.0 & Wartenberg, Germany & VDM 1996 as MN 8/9 & MN 6 \\
\hline BSPG 1958 I 34 & $\mathrm{C} 1 / \mathrm{rt}$ & 25.4 & 28.9 & Wartenberg, Germany & VDM 1996 as MN 8/9 & MN 6 \\
\hline HLD Din 40 & $\mathrm{C} 1 / \mathrm{lt}$ & 26.3 & 29.9 & Esselborn, Germany & VDM 1996 as MN 9 & MN 6 \\
\hline NMM 1930/375 & $\mathrm{C} 1 / \mathrm{lt}$ & 37.4 & 32.0 & Wissberg, Germany & VDM 1996 as MN 9 & MN 6 \\
\hline MNCN NM 18004 & $\mathrm{C} 1 / \mathrm{rt}$ & 29.3 & 28.5 & Cerro del Ortero, Spain & VDM 1996 & MN 7 \\
\hline $\mathrm{UCBL}$ sans $\mathrm{n}^{\circ}$ & $\mathrm{C} 1 / \mathrm{lt}$ & 26.7 & 30.5 & La Grive St-Alban, France & VDM 1996 & MN 7 \\
\hline MGL LGr 717 & $\mathrm{C} 1 / \mathrm{lt}$ & 32.5 & 36.6 & La Grive St-Alban, France & VDM 1996 & MN 7 \\
\hline MGL LGr 1660 & $\mathrm{C} 1 / \mathrm{rt}$ & 34.0 & 33.1 & La Grive St-Alban, France & VDM 1996 & MN 7 \\
\hline MNHN Si 158 & $\mathrm{C} 1 / \mathrm{lt}$ & 17.4 & 22.3 & Simorre, France & VDM 1996 & MN 7 \\
\hline MNHN Si 157 & $\mathrm{C} 1 / \mathrm{lt}$ & 25.7 & 25.3 & Simorre, France & VDM 1996 & MN 7 \\
\hline NMW SK 1614 & $\mathrm{C} 1 / \mathrm{lt}$ & 37.2 & 42.6 & Eichkogel, Austria & VDM 1996 as MN 6 & MN 7/8 \\
\hline NMW SK 1614 & $\mathrm{C} 1 / \mathrm{rt}$ & 38.1 & 43.5 & Eichkogel, Austria & VDM 1996 as MN 6 & MN 7/8 \\
\hline MNHN HGP 46 & $\mathrm{C} 1 / \mathrm{lt}$ & 45.5 & 42.0 & Bonnefont, France & Own, 2019; VDM 1996 as $43.3 \times 41.3$ & MN 7/8 \\
\hline
\end{tabular}


Table 2. continued.

\begin{tabular}{|l|c|l|l|l|l|c|}
\hline \multicolumn{1}{|c|}{ Catalogue no. } & Tooth & Dap & Dvd & \multicolumn{1}{c|}{ Locality } & \multicolumn{1}{c|}{ Data source and comments } & Correlation \\
\hline MHNCF 48 & $\mathrm{C} 1 / \mathrm{lt}$ & 24.2 & 26.3 & La Chaux-de-Fonds, Switzerland & VDM 1996 & MN 7/8 \\
\hline MHNCF 14 & $\mathrm{C} 1 / \mathrm{rt}$ & 41.9 & 44.3 & La Chaux-de-Fonds, Switzerland & VDM 1996 & MN 7/8 \\
\hline MHNCF 45 & $\mathrm{C} 1 / \mathrm{rt}$ & 42.3 & 43.2 & La Chaux-de-Fonds, Switzerland & VDM 1996 & MN 7/8 \\
\hline MNCN NM 18009 & $\mathrm{C} 1 / \mathrm{lt}$ & 39.2 & 38.6 & Cerro del Ortero, Spain & VDM 1996 as MN 7 & MN 8 \\
\hline MGL LGr 728 & $\mathrm{C} 1 / \mathrm{lt}$ & 38.7 & 37.4 & La Grive St-Alban, France & VDM 1996 as MN 7 & MN 8 \\
\hline MGL LGr 716 & $\mathrm{C} 1 / \mathrm{lt}$ & 42.6 & 40.7 & La Grive St-Alban, France & VDM 1996 as MN 7 & MN 8 \\
\hline UN & $\mathrm{C} 1 / \mathrm{rt}$ & 38.8 & 36.9 & Le Locle, Switzerland & VDM 1996 as MN 7 & MN 8 \\
\hline BSPG 1950 I 34b & $\mathrm{C} 1 / \mathrm{rt}$ & 35.9 & 36.9 & Massenhausen, Germany & VDM 1996 & MN 8 \\
\hline BSPG 1957 I 218 & $\mathrm{C} 1 / \mathrm{rt}$ & 36.4 & 43.2 & Massenhausen, Germany & VDM 1996 & MN 8 \\
\hline BSPG 1951 I 34 & $\mathrm{C} 1 / \mathrm{rt}$ & 37.6 & 39.8 & Massenhausen, Germany & VDM 1996 & MN 8 \\
\hline BSPG 1956 I 135 & $\mathrm{C} 1 / \mathrm{rt}$ & 39.4 & 38.3 & Massenhausen, Germany & VDM 1996 & MN 8 \\
\hline MGSCB 48579 & $\mathrm{C} 1 / \mathrm{lt}$ & 37.5 & 40.1 & St Quirze, Spain & VDM 1996 & MN 8 \\
\hline MGSCB 48578 & $\mathrm{C} 1 / \mathrm{lt}$ & 37.9 & 39.9 & St Quirze, Spain & VDM 1996 & MN 8 \\
\hline MGSCB 48580 & $\mathrm{C} 1 / \mathrm{lt}$ & 45.7 & 47.2 & St Quirze, Spain & VDM 1996 & MN 8 \\
\hline IPS 1674 & $\mathrm{C} 1 /$ & 54.0 & 44.0 & St Quirze, Spain & VDM 1996 & MN 8 \\
\hline MGSCB 48581 & $\mathrm{C} 1 / \mathrm{rt}$ & 40.3 & 41.8 & St Quirze, Spain & VDM 1996 & MN 8/9 \\
\hline MGSCB 48582 & $\mathrm{C} 1 / \mathrm{rt}$ & 41.0 & 31.0 & St Quirze, Spain & VDM 1996 & MN 8/9 \\
\hline MGSCB 48512 & $\mathrm{C} 1 / \mathrm{lt}$ & 41.4 & 45.7 & Hostalets, Spain & VDM 1996 & MN 8/9 \\
\hline MGSCB 48513 & $\mathrm{C} 1 / \mathrm{lt}$ & 45.1 & 44.8 & Hostalets, Spain & VDM 1996 & VDM $8 / 9$ \\
\hline MGSCB 48511 & $\mathrm{C} 1 / \mathrm{lt}$ & 49.7 & 45.8 & Hostalets, Spain & Own, 2019 \\
\hline MGSCB 48514 & $\mathrm{C} 1 / \mathrm{rt}$ & 37.9 & 38.1 & Hostalets, Spain & \\
\hline EUNHM PV 3075 & $\mathrm{C} 1 / \mathrm{lt}$ & 54.4 & 51.4 & Nebisuyu, Turkey & \\
\hline
\end{tabular}

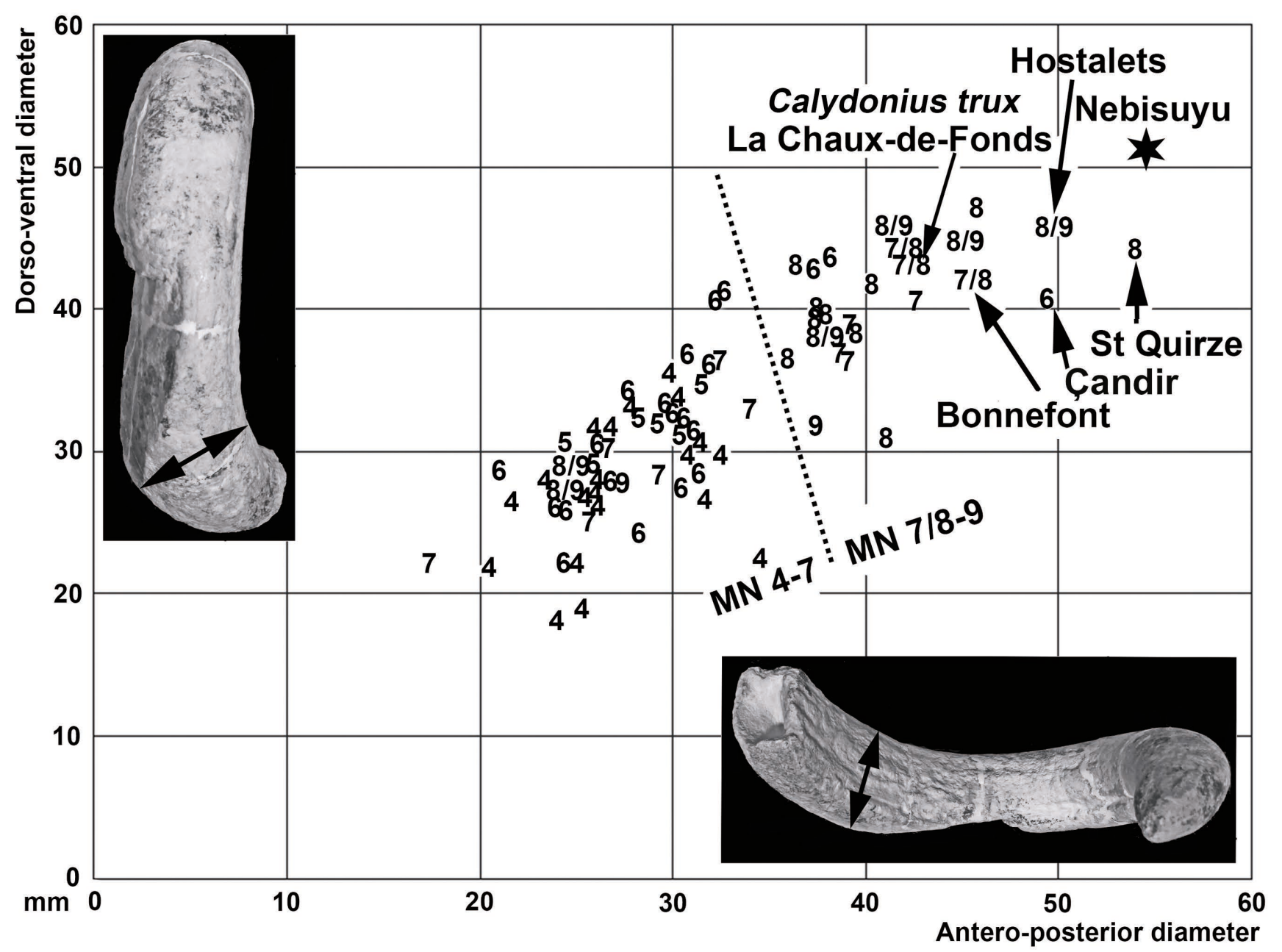

Text-fig. 15. Bivariate plots of antero-posterior diameter and dorso-ventral diameter of upper male canines of European Listriodontinae arranged by MN zonation (MN 4 - MN 9). Nebisuyu (star) and other large specimens are highlighted. There are some small individuals which have been correlated to MN 8/9 which could be mis-correlated (probably from MN 6), just as there are some large specimens reported to be from MN 7 but which are more likely to be from MN 7/8 or MN 8. Large specimens correlated to MN 6 are from Çandir, Turkey, and Eichkogel, Austria, suggesting a possible mis-correlation of the age of these specimens, at least for the material from the latter locality. 
Table 3. Measurements (in mm) of teeth of Listriodon splendens from Helsighausen, Switzerland and Hostalets de Pierola, Spain. BLB - bucco-lingual breadth, It - left, MDL - mesiodistal length, rt - right.

\begin{tabular}{|l|c|c|c|l|}
\hline \multicolumn{1}{|c|}{ Catalogue no. } & Tooth & MDL & BLB & \multicolumn{1}{|c|}{ Locality } \\
\hline PIMUZ A/V 1237 & $\mathrm{I} 1 / \mathrm{lt}$ & 30.0 & 14.0 & Helsighausen \\
\hline PIMUZ A/V 1236 & $\mathrm{m} / 2 \mathrm{rt}$ & 21.0 & 18.0 & Helsighausen \\
\hline PIMUZ A/V 1236 & $\mathrm{m} / 3 \mathrm{rt}$ & 33.0 & 21.1 & Helsighausen \\
\hline PIMUZ A/V 1236 & $\mathrm{p} / 3 \mathrm{rt}$ & 16.7 & 11.3 & Helsighausen \\
\hline PIMUZ A/V 1236 & $\mathrm{p} / 4 \mathrm{rt}$ & 17.0 & 14.0 & Helsighausen \\
\hline MNHN 1952-3 & $\mathrm{m} / 2 \mathrm{lt}$ & 23.0 & 19.3 & Hostalets de Pierola \\
\hline MNHN 1952-3 & $\mathrm{m} / 3 \mathrm{lt}$ & 35.0 & 22.7 & Hostalets de Pierola \\
\hline
\end{tabular}

D i s c u s s i o n. The skull of Listriodon from Nebisuyu is of an old individual - the M3/s are heavily worn and all that remains of the $\mathrm{M} 1 / \mathrm{s}$ are stubs with small remnants of enamel at the bases of the paracone and protocone. The premaxillae and parts of the nasals are broken off and the skull has suffered slight lateral compression and diverse fractures affect much of the surface of the specimen. Of the dentition, only the $\mathrm{P} 2 /-\mathrm{M} 3 /$ are preserved on both sides, but from the same locality there is a left upper canine in a fragment of maxilla which could well be from the same individual. The neurocranium is almost complete but has been slightly compressed from side to side and has suffered soft-sediment distortion and some displacement of bony parts. The sutures are difficult to make out due to the advanced age of the individual, but the contact between the lachrymal and frontal can be made out on both sides, the surface of the lachrymal being smooth, whereas that of the frontal above it is thickened and rugose.

What is remarkable about the Nebisuyu specimen is the fact that it preserves the frontals, which are rarely represented in the fossil record of the genus, the few specimens retaining this part of the skull being a large female of Listriodon splendens from Toril, Spain (Pickford and Morales 2003), a fossil of Listriodon xinanensis from Xinan, China (Chen, 1986) and a specimen from Bézian, France, attributed to Bunolistriodon lockharti (PomeL, 1848) by Ginsburg and Bulot (1987). Lopholistriodon kidogosana from Ngorora, Kenya (Pickford 1986) also preserves the frontals, but, as its name implies, it is a considerably smaller animal than Listriodon splendens. Specimens of Eurolistriodon adelli Pickford et Moya-sola, 1995, from Els Casots, Spain and Eurolistriodon tenarezensis ORLIAC, 2006, from Montréaldu-Gers, France preserve the frontals but the fossils are highly compressed and yield little information about their morphology. A partial skull from Chinji, Pakistan, also
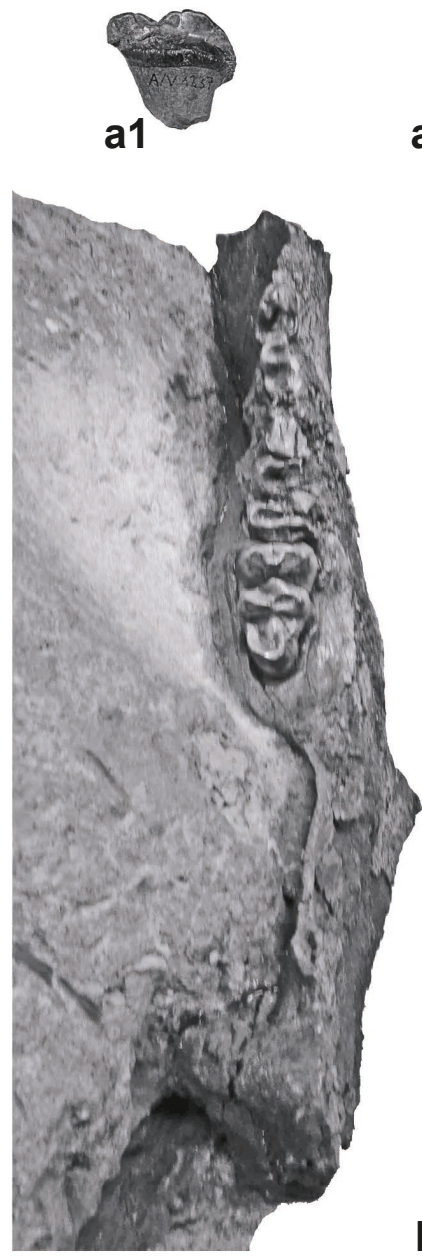
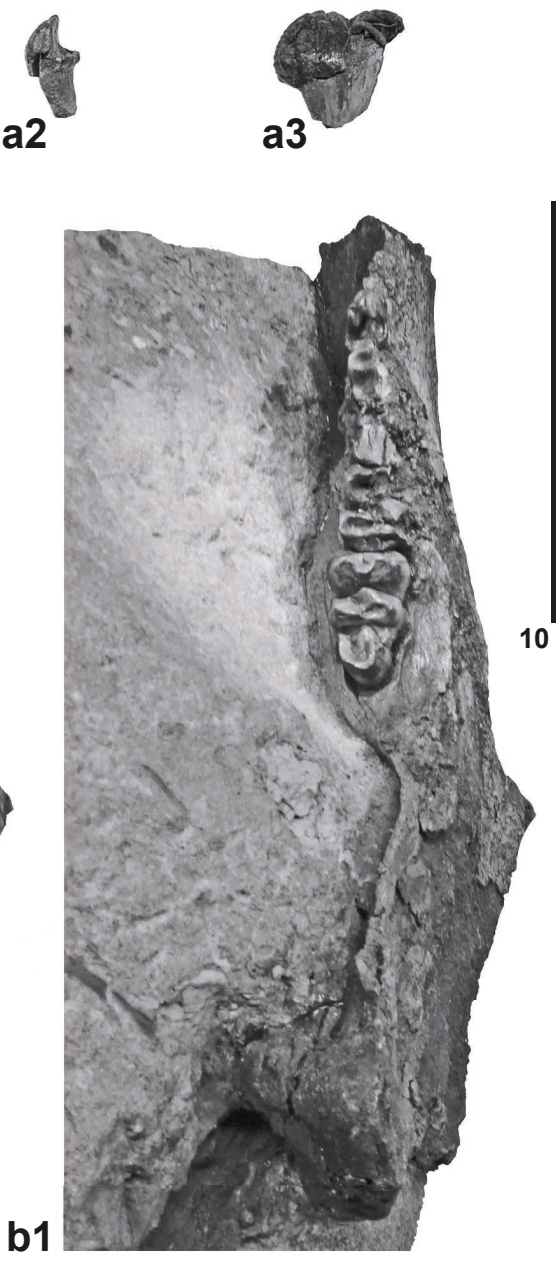

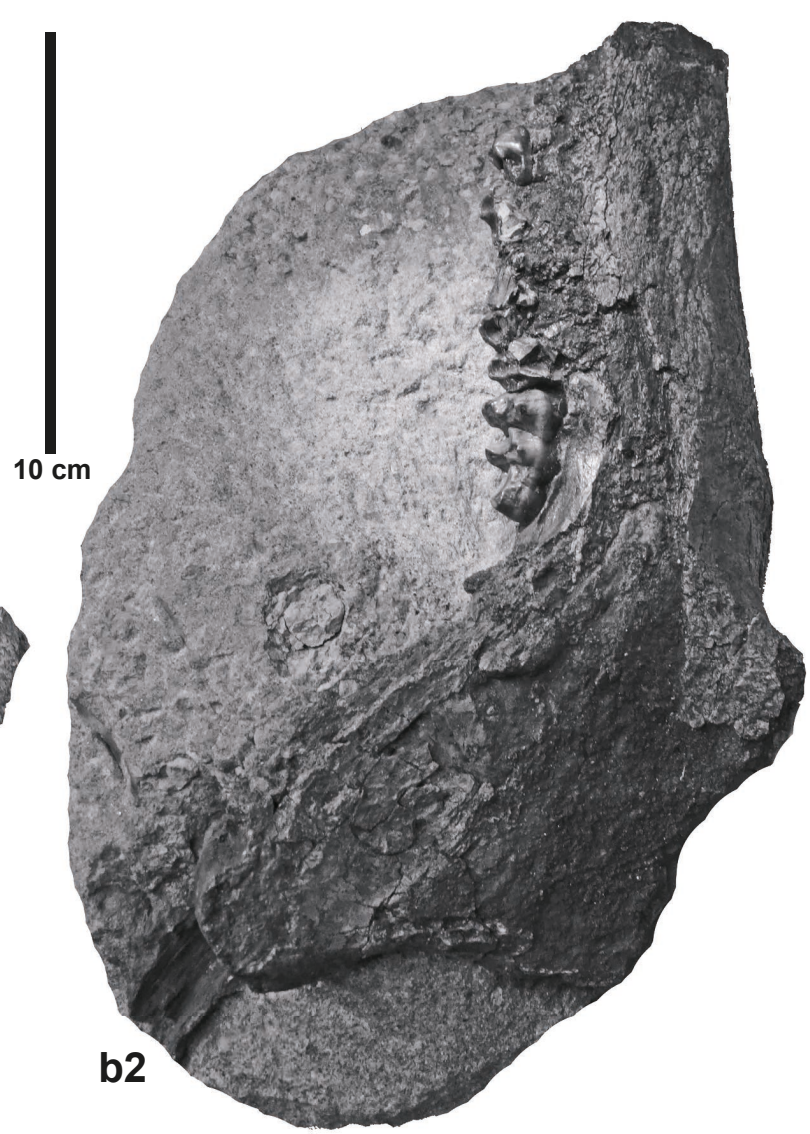

Text-fig. 16. Listriodon splendens from Helsighausen, Switzerland. a: PIMUZ A/V 1237, left I1/ (a1 - lingual, a2 - mesial, a3 - labial views); b: PIMUZ A/V 1236, right mandible containing p/3-m/3 (b1 - stereo occlusal view, b2 - buccal view). 

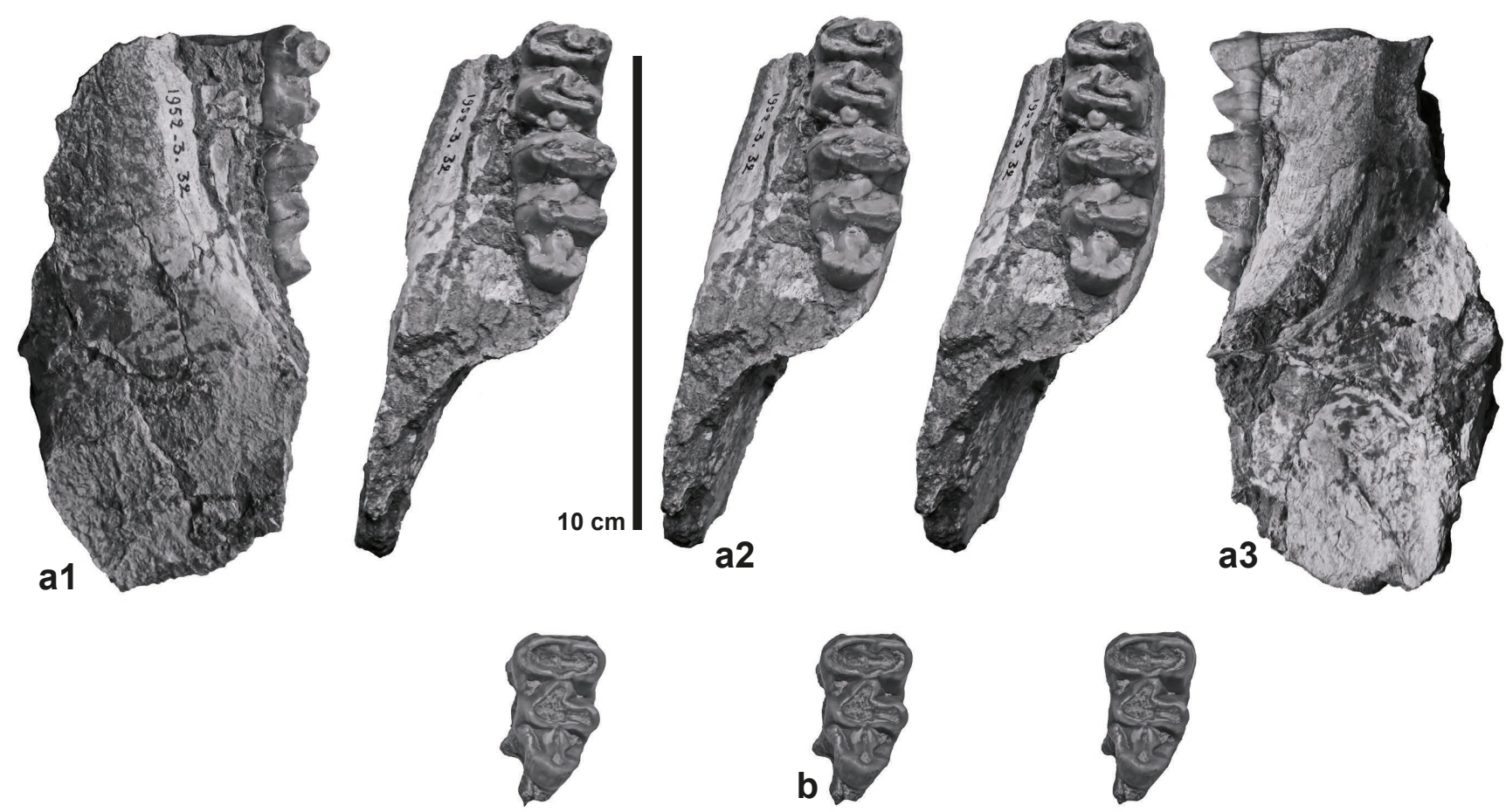

Text-fig. 17. Listriodon splendens from Hostalets de Pierola, Spain. a: MNHN 1952-3, left mandible of containing $\mathbf{m} / 2$ and $\mathbf{m} / 3$ (a1 - buccal view, a2 - stereo occlusal view, a3 - lingual view); b: MGM, left m/3, stereo occlusal view.

preserves part of the frontal bones (Van der Made 1996). Thus, despite its crushed and distorted morphology, the Nebisuyu fossil is of great interest in revealing aspects of the morphology of part of the skull that is rarely represented in the palaeontological record.

Furthermore, the Nebisuyu skull is unusual among Suidae in showing thickened and inflated frontals which rise abruptly just distal to the naso-frontal zone, well in front of the orbits, thereby forming a solid base for a single sagittal horn-like protuberance, the ossicone. The apex of the ossicone itself is missing but its broken base measures about $50 \mathrm{~mm}$ antero-posteriorly by ca. $31 \mathrm{~mm}$ from side to side. Lower down, the solid base of the horn-like structure measures $65 \mathrm{~mm}$ across and it overhangs the lachrymals on both sides $(7 \mathrm{~mm}$ on the left and $25 \mathrm{~mm}$ on the right, the latter measurement possibly exaggerated by inward, post-mortem displacement of the lachrymal). The swollen, inflated and somewhat rugose appearance of the surface of the frontals extends distally from this horn base and affects the post-orbital processes which are enlarged and show a rugose outer surface. Distal to the post-orbital processes the frontals display a more usual suid-like appearance of the fronto-parietal parts, the temporal ridges lying well apart from each other (i.e., no saggital crest is present). However, the nuchal area is deeply excavated and the distal margin of the temporo-nuchal crest invaginates anteriorly rather than being almost straight and transversely oriented as in many suids (Stehlin 1899, 1900).

The only other suids that are known to have possessed frontal protuberances are Kubanochoerinae GABUNIA, 1958 (Gabunia 1958, 1960) but the position and structure of the horns in this subfamily are different in the Nebisuyu specimen, the base of the horn being more distally positioned (above the orbits) and the frontal bones on which it is posed are not raised dorsally, nor are they thickened to any great extent. Some nyanzachoeres possess horn-like protuberances on the zygomatic arches (Gebreyesus 2011, Reda et al. 2017) but these are radically different from the horns of listriodonts and kubanochoeres, not only by their positions, but also by the fact that they are present on both sides of the skull.

\section{General discussion and comparisons}

Were it not for the swollen, domed frontal bone and the presence of an ossicone on this skull, it would readily fit into the definition of Listriodon splendens as a large, old, male individual, and in particular it would accord with current concepts of the subspecies Listriodon splendens major. The latter subspecies is known from MN 7, MN 8 and MN 8/9 in Spain and Portugal, which agrees with the estimated correlation of Nebisuyu to MN 8. As such the skull would not attract undue attention, representing a discovery mainly of biogeographic interest, extending, as it does, the known range of the taxon well to the east of its previously documented range (Text-fig. 18).

However, the presence of a thickened, domed frontal bone with a rugose surface, apparently topped by an ossicone, raises a series of questions regarding the taxonomy and ecology of the lineage that it represents. Can the specimen be attributed to an existing taxon? Does the presence of a frontal protuberance indicate affinities with other suids, notably Kubanochoerinae, which possess frontal horns? What selective pressures led to the development of such a cranial structure?

Concerning the taxonomic affinities of the Nebisuyu skull, we have little hesitation is attributing it to Listriodon splendens. The dental evidence is striking in this regard, the 
$\mathrm{M} 3 /$, which is the only molar retaining reliable indications of the crown morphology, is clearly that of a highly lophodont species of Listriodon in which the median accessory cusplet does not block the median transverse valley (see for example Stehlin 1900: pl. 6, fig. 19, for a figure of an M3/ from La Chaux-de-Fonds, Switzerland). What remains of the P4/ underlines this identification, as do the dimensions of the cheek teeth.

If one accepts the notion of subspecies (or evolutionary stages of Van der Made 1996) then the Nebisuyu skull would be attributed to Listriodon splendens major (or to Listriodon splendens evolutionary stage III). The only other known skull of this subspecies is from Toril, Spain (MN 7), but it does not possess a thickened frontal bone, nor any sign of an ossicone, probably because it is female (Pickford and Morales 2003).

As for any possibility of a close relationship between the Nebisuyu specimen and kubanochoeres, this can be discounted because the form of the frontal bone, the way it is thickened and domed, and the positioning of the ossicone on its top is radically different from the situation in Kubanochoerus gigas (PEARSON, 1928) and other species of the genus (Gabunia 1958, 1960). It is also divergent from the frontal swelling in the genus Libycochoerus (only known in Libycochoerus massai Arambourg, 1961; Arambourg 1961, 1963).

In Kubanochoerus Gabunia, 1955, the base of the frontal horn is located well behind the anterior root of the zygomatic arch: in the Nebisuyu skull it is above the root of the zygomatic arch, and is thus in a forward position. In the Nebisuyu specimen, the vertical part of the frontal containing the supra-orbital grooves lies $92 \mathrm{~mm}$ anterodorsally from the anterior edge of the orbit whereas, in Kubanochoerus, the corresponding part is close to the orbit and almost directly above it. The posterior part of the ossicone base is positioned in front of the orbit in the Nebisuyu skull, but in Kubanochoerus the posterior margin of the base of the frontal protuberance is well behind the orbit. In the Nebisuyu individual the post-orbital process is thickened, antero-posteriorly enlarged, and possesses a rugose surface, whereas in Kubanochoerus it is gracile, smooth and descends only a short way as in suids in general.

A further striking difference between the Nebisuyu skull and those of Kubanochoerus concerns the snout. In the Nebisuyu specimen the anterior part of the face is relatively short, the dorsal profile curving sharply upwards at the nasofrontal suture, whereas in Kubanochoerus gigas, the frontal bone anterior to the horn base does not rise significantly above the level of the nasals (Text-fig. 19). Thus in Kubanochoerus the snout appears distinctly elongated when compared to the foreshortened facial profile in the Nebisuyu individual (even taking into account the absence of the premaxilla in the Turkish skull). The Toril skull from Spain confirms this inference (Pickford and Morales 2003).

\section{Ecological considerations}

In animals in general, the presence of horns on the head has been the subject of much research, several scenarios having been proposed to explain the agencies of natural selection that resulted in their evolution. These fall broadly into two categories which can be called, for the sake of simplicity, exogenic and endogenic. Exogenic selective pressures arise from interactions between the species concerned and other elements in the biosphere and the environment, such as predator-prey interactions or climate parameters, vegetation categories etc. Endogenic selective pressures concern interactions between members of the same

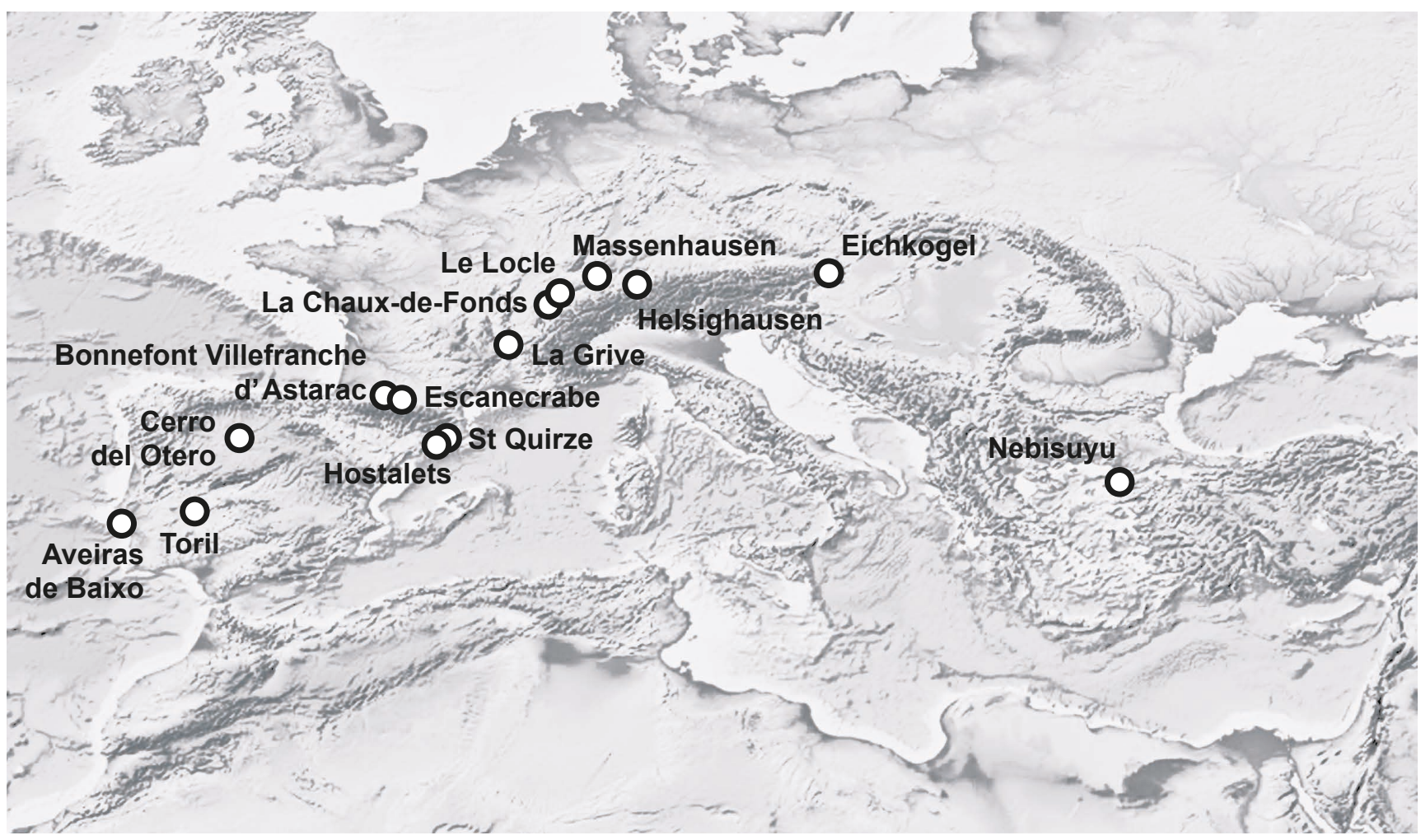

Text-fig. 18. Distribution of large specimens of Listriodon splendens from MN 7, MN 8 and MN 8/9. 


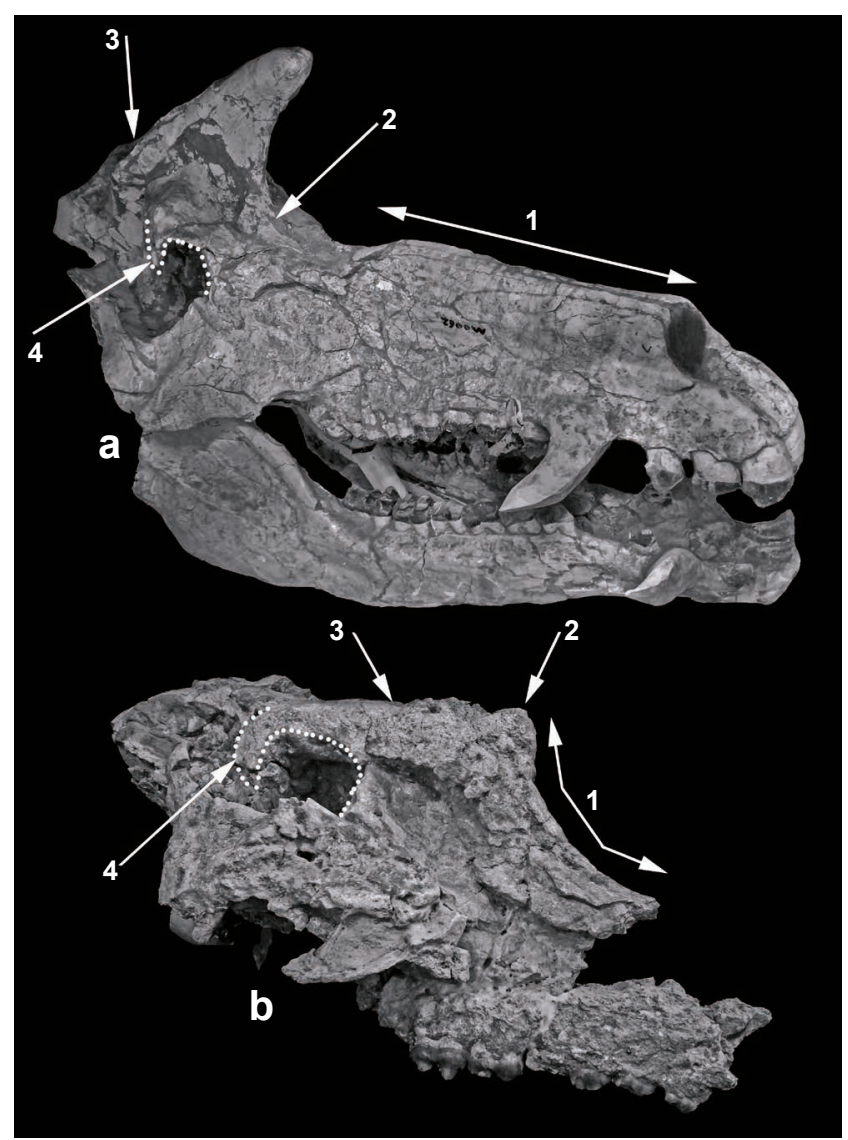

Text-fig. 19. Comparison between the skulls of (a) Kubanochoerus gigas from China (Hezheng Museum, M0062) and (b) Listriodon splendens (EUNHM PV 3075). 1 - profile of dorsal edge of nasals and frontal bones, 2 - anterior base of frontal protuberance, 3 - posterior base of frontal protuberance, 4 post-orbital process. The superior and posterior margins of the orbits are outlined for ease of reference (not to scale).

species, such as male-to-male combat and male dominance over females and youngsters.

Large, easily visible canines occur in many lineages of suids, and it is likely that a major selective pressure was predator deterrance, but there could also have been an element of sexual selection involved, because a goodly sample of suid taxa is dimorphic in canine dimensions and morphology, males often possessing large, laterally flaring canines, while females may have small, more vertically inserted canines (Stehlin 1899, 1900). In some suids, such as the Wart Hog (Phacochoerus) both males and females possess large canines, probably as a result of exogenic selection involving predators.

The fact that most Neogene suids possessed large canines suggests that these sufficed for generally discouraging predator attention. If this is so, then one needs to search for an endogenic explanation of the presence of frontal protuberances in Kubanochoerus (and now Listriodon) because both these genera possessed relatively large laterally projecting canines.

Many suids (Sus, Dasychoerus, Phacochoerus, Hylochoerus) indulge in male-to-male combat during the rut season. Males engaging in such behaviour typically push their heads together and use brute force to vanquish an opponent (Ewer 1958) and often also use side swipes of the head and canines. The presence of thickened skin and warts on the heads in some of these taxa has usually been explained in terms of male-to-male combat, with the warty pads protecting the individuals from serious injury.

Given the propensity for head-to-head contact during male-to-male combat in several extant suids, it is possible that Listriodon indulged in much the same form of combat, and this could account for the thickened frontal bone that aged individuals such as the Nebisuyu individual possessed. The female cranium from Toril, Spain, is also of an aged individual, perhaps even more dentally aged than the Nebisuyu specimen, but as would be expected for a female, it shows no signs of frontal bone thickening. If these two specimens belong to the same taxon, as is suggested by the overall similarities in their morphology and dental characteristics, then it is likely that thickening of the frontal bone in the Nebisuyu male specimen was related to sexual selection. The development of an ossicone atop the thickened frontal bone would then represent an endogenic feature related to male-on-male combat in the species.

A comparable set of circumstances could explain the presence of frontal protuberances in Kubanochoerus, but there is a significant difference from Listriodon, in that the frontal bone does not appear to be thickened in kubanochoeres, the horn atop the frontal being highly visible and impressive, but not well-supported on a solid bony foundation. The fragility of the frontal bone in Kubanochoerus suggests instead that the male-on-male interaction in this genus did not imply serious head-to-head contact, but was more along the lines of a highly visible combat deterrant. Listriodon, in contrast, appears to have indulged in serious head-banging between males, implicating not just the frontal zone, but also the post-orbital processes as well as the zygomatic arches, the lateral surfaces of which are thickened and rugose. The latter observations indicate an important element of head side-swiping in Listriodon.

Thickening of the frontal bone could increase during ontogeny, such that older males would possess thicker frontal bones than younger individuals. The Nebisuyu specimen, representing an aged (senile) member of the species, could have experienced many head-to-head encounters during its lifetime, with the concomitant result that its frontal and zygomatic bones became exceptionally thick. The presence of dermal bone fused to the frontal (the ossicone) indicates that the head-to-head contact in this genus was not a gentle affair.

The deeply concave nuchal area of the Nebisuyu skull and the thickened bony margins of the nuchal depression indicate that the nuchal musculature was strongly developed, much more so than would be required for activities related predominantly to acquisition of food, which suggests an alternative possibility: the role of forceful head-to-head contact and cranial side-swiping between individuals of this taxon during dominance encounters, likely during the rut season.

\section{Acknowledgements}

M. P. thanks the Muséum National d'Histoire Naturelle, Paris, for support and Ege University Natural History Museum for providing access to the fossils described 
herein. Serdar Mayda and Tanju Kaya were funded by EGE University Research Grants TTM/2009/001, TTM/2013/001 and TTM/2015/001.

\section{References}

Ameghino, F. (1904): Nuevas especies de mamíferos, cretáceos y terciarios de la República Argentina [New species of mammals, Cretaceous and Tertiary, from the Republic of Argentina]. - Anales de la Sociedad Cientifica Argentina, 56-58: 1-142. (in Spanish)

Arambourg, C. (1961): Note préliminaire sur quelques Vertébrés nouveaux du Burdigalien de Libye. - Comptes Rendus sommaires de la Société géologique de France, 1961: 107-108.

Arambourg, C. (1963): Le genre Bunolistriodon Arambourg, 1933. - Bulletin de la Société géologique de France, 7(5): 903-911. https://doi.org/10.2113/gssgfbull.S7-V.6.903

Bayle, E. (1856): Notice sur le Listriodon splendens et quelques autres mammifères découverts dans la mollasse miocène de la Chaux-de-Fonds. - Bulletin de la Société Géologique de France, sér. 2, 13: 24-30.

Blainville, H. M. D. de (1847): Ostéographie ou description iconographique comparée des Mammifères récénts et fossiles. 4, AA, Sur les Hippopotames et les Cochons. Bertrand, Paris, 248 pp., 93 pls, Atlas 4.

Çağatay, M. N., Görür, N., Alpar, B., Saatçılar, R., Akkök, R., Sakınç, M., Yüce, H., Yaltırak, C., Kuşçu, İ. (1999): Geological evolution of the Gulf of Saros, NE Aegean Sea. - Geo-Marine Letters, 18: 1-9. https://doi.org/10.1007/s003670050045

Çağatay, M. N., Görür, N., Flecker, R., Sakınç, M., Tünoğlu, C., Ellam, R., Krijgsman, W., Vincent, S., Dikbaş, A. (2006): Paratethyan-Mediterranean connectivity in the Sea of Marmara region (NW Turkey) during the Messinian. - Sedimentary Geology, 188-189: 171-187. https://doi.org/10.1016/j.sedgeo.2006.03.004

Chen Guanfang (1986): A new species of Listriodon Meyer (Suidae, Artiodactyla, Mammalia) from Xinan, Henan. Vertebrata PalAsiatica, 24(4): 295-307, pls 1-3.

Crouzel, F. (1980): Le gisement fossilifère Miocène supérieur de la tuilerie Dubernard à Trie-sur-Baïse (65) et ses enseignements. - Bulletin de la Société d'Histoire naturelle de Toulouse, 116: 247-253.

Ewer, R. F. (1958): Adaptive features in the skulls of African Suidae. - Proceedings of the Zoological Society of London, 131(1): 135-155. https://doi.org/10.1111/j.1096-3642.1958.tb00637.x

Gabunia, L. K. (1955): Novyy predstavitel' Suidae iz srednego miotsena Belomechetskoy (Severnyy Kavkaz) [New representative of Suidae from middle Miocene of Belomechetskaya locality (North Caucasus)]. - Doklady AN SSSR, 102(6): 1203-1206. (in Russian)

Gabunia, L. K. (1958): O cherepe rogatoy iskopaemoy svin'i iz srednego miotsena Kavkaza [On a skull of a horned pig from the middle Miocene of the Caucasus]. Doklady AN SSSR, 118(6): 1187-1190. (in Russian)

Gabunia, L. K. (1960): Kubanochoerinae, nouvelle sousfamille de porcs du Miocene moyen de Caucase. - Vertebrata PalAsiatica, 4(2): 87-97.
Gasparini, G. M., Soibelzon, E., Zurita, A. E., Miño-Boilini, A. R. (2010): A review of the Quaternary Tayassuidae (Mammalia, Artiodactyla) from the Tarija Valley, Bolivia. - Alcheringa, 34(1): 7-20.

https://doi.org/10.1080/03115510903277717

Gebreyesus, H. (2011): The origin and evolution of Notochoerus euilus (Suidae): Fossil evidence from Woranso-Mille, Central Afar, Ethiopia; MSc Thesis. - MS, University of Addis Ababa, Addis Ababa, Ethiopia, 122 pp. (copy in personal library of M. Pickford).

Gervais, P. (1859): Zoologie et Paléontologie françaises ( $2^{\text {nd }}$ ed.). - Bertrand, Paris, 544 pp.

Ginsburg, L., Bulot, C. (1987): Les Suiformes (Artiodactyla, Mammalia) du Miocene de Bézian (Gers). - Bulletin du Muséum national d'Histoire naturelle, Sér. 4, Section C, 9(4): 455-469.

Gray, J. E. (1821): On the natural arrangement of vertebrose animals. - London Medical Repository, 15(1): 296-310.

Hernandez-Pacheco, E., Dantin Cereceda, J. (1915): Geología y Paleontología del Mioceno de Palencia [Miocene Geology and Palaeontology of Palencia]. Memoria, Comision de Invesigaciones paleontologicas y prehistoricas, 5: 1-295, 62 pls. (in Spanish)

Kaya, T. (1989): Mammalian fauna of Alçıtepe (Gelibolu Peninsula) surroundings: Perissodactyla foundings. Geological Bulletin of Turkey, 32: 79-89.

Kaya, T., Mayda, S. (2012): Research on New Fossil Mammal Localities from Dardanelles (Çanakkale, Tekirdağ) and Western Anatolia (Muğla, Denizli); Report. - MS, Report of Ege University Scientific Research, No: 2009/ TTM/002, Izmir, Turkey, 124 pp. (copy in personal library of T. Kaya)

Kayseri Özer, M. S., Akgün, F., Mayda, S., Kaya, T. (2014): Palynofloras and vertebrates from Mugla-Ören region (SW Turkey) and palaeoclimate of the Middle Burdigalian-Langhian period in Turkey. - Bulletin of Geosciences, 89(1): 137-162. https://doi.org/10.3140/bull.geosci.1407

Mein, P. (1989): Updating of MN zones. - In: Fahlbusch, V., Mein, P., Lindsay, E. H. (eds), European Neogene mammal chronology. Plenum Press, New York, pp. 73-90. https://doi.org/10.1007/978-1-4899-2513-8_6

Meyer, H. von (1846): [Mitteilungen an Prof. Bronn]. Neues Jahrbuch für Mineralogie, Geognosie, Geologie und Petrefakten-Kunde, 1846: 462-476. (part about "tertiäre Wirbelthiere zu la-Chaux-de-Fonds, theils von neuen Geschlechtern" on pp. 464-470)

Newton, R. B. (1904): Notes on the post-Tertiary and Tertiary Fossils obtained by Col. English from the District surrounding the Dardanelles. - Quarterly Journal of the Geological Society, 60: 277-292. https://doi.org/10.1144/GSL.JGS.1904.060.01-04.22

Orliac, M. (2006): Eurolistriodon tenarezensis sp. nov. from Montreal-du-Gers (France): Implications for the systematics of the European Listriodontinae (Suidae, Mammalia). - Journal of Vertebrate Paleontology, 26(4): 967-980.

https://doi.org/10.1671/0272-4634(2006)26[967:ETSN$\mathrm{FM}] 2.0 . \mathrm{CO} ; 2$

Owen, R. (1848): Description of teeth and portions of jaws of two extinct Anthracotherioid quadrupeds (Hyopo- 
tamus vectianus and Hyop. bovinus) discovered by the Marchioness of Hastings in the Eocene deposits on the NW coast of the Isle of Wight: with an attempt to develop Cuvier's idea of the Classification of Pachyderms by the number of their toes. - Quarterly Journal of the Geological Society of London, 4: 103-141. https://doi.org/10.1144/GSL.JGS.1848.004.01-02.21

Pearson, H. S. (1928): Chinese fossil Suidae. - Palaeontologia Sinica, Ser. C, 5(5): 1-75.

Pickford, M. (1986): A revision of the Miocene Suidae and Tayassuidae (Artiodactyla, Mammalia) of Africa. - Tertiary Research Special Paper, 7: 1-83.

Pickford, M., Morales, J. (2003): New Listriodontinae (Suidae, Mammalia) from Europe and a review of listriodont evolution, biostratigraphy and biogeography. - Geodiversitas, 25(2): 347-404.

Pickford, M., Moya Sola, S. (1995): Eurolistriodon gen. nov. (Suoidea, Mammalia) from Els Casots, early middle Miocene, Spain. - Proceedings of the Koninklijke Nederlandse Akademie van Wetenschappen, 98(4): 343-360.

Pickford, M., Wilkinson, A. F. (1975): Stratigraphic and phylogenetic implications of new Listriodontinae from Kenya. - Netherlands Journal of Zoology, 25: 128-137. https://doi.org/10.1163/002829675X00191

Pomel, A. (1848): Observations paléontologiques sur les hippopotames et les cochons. - Archives des Sciences physique et naturelle, Genève, 8: 155-162.

Reda, H., Lazagabaster, I., Haile-Selassie, Y. (2017): Newly discovered crania of Nyanzachoerus jaegeri (Tetraconodontinae, Suidae, Mammalia) from the Woranso-Mille (Ethiopia) and reappraisal of its generic status. - Journal of Mammalian Evolution, 26: 1-21. https://doi.org/10.1007/s10914-017-9398-5
Roman, F. (1907): 1ère partie - Paléontologie. - In: Roman, F., Fliche, M., Torres, A., Le Néogene continental dans la basse vallée du Tage (rive droite) partie Paléontologie. Commission du Service géologique de Portugal, 1907: $1-78,5$ pls.

Sen, S. (2016): Historical background. - In: Sen, S. (ed.), Late Miocene mammal locality of Küçükçekmece, European Turkey. Geodiversitas, 38(2): 153-173. https://doi.org/10.5252/g2016n2a2

Stehlin, H. G. (1899): Ueber die Geschichte des Suiden-Gebisses. Erster Teil. - Abhandlungen der Schweizerischen paläontologischen Gesellschaft, 26: 1-336.

Stehlin, H. G. (1900): Ueber die Geschichte des Suiden-Gebisses. Zweiter Teil. - Abhandlungen der Schweizerische paläontologisches Gesellschaft, 27: 337-527, 10 pls.

Sümengen, M., Terlemez, İ., Şentürk, K., Karaköse, C., Erkan, E., Ünay, E., Gürbüz, M., Atalay, Z. (1987): Stratigraphy, sedimentology and tectonics of the Gelibolu Peninsula and Southwestern Thrace Basin. - Mineral Research and Exploration Institute, Ankara, Report No. 8128: 1-146.

Ünay, E., de Bruijn, H. (1984): On some Neogene rodent assemblages from both sides of the Dardanelles, Turkey. Newsletters in Stratigraphy, 13(3): 119-132. https://doi.org/10.1127/nos/13/1984/119

Van der Made, J. (1996): Listriodontinae (Suidae, Mammalia), their evolution, systematics and distribution in time and space. - Contributions to Tertiary and Quaternary Geology, 33: 3-254.

Van der Made, J. (1998): The first described listriodont remains. - Bulletin de la Société Neuchâteloise des Sciences Naturelles, 121: 40-44. 